Portland State University

PDXScholar

7-19-1993

\title{
The Feminine Poetic Voice in the Rymes of Pernette du Guillet
}

Darcy Renee Murphey

Portland State University

Follow this and additional works at: https://pdxscholar.library.pdx.edu/open_access_etds

Part of the French and Francophone Language and Literature Commons Let us know how access to this document benefits you.

Recommended Citation

Murphey, Darcy Renee, "The Feminine Poetic Voice in the Rymes of Pernette du Guillet" (1993).

Dissertations and Theses. Paper 4686.

https://doi.org/10.15760/etd.6570

This Thesis is brought to you for free and open access. It has been accepted for inclusion in Dissertations and Theses by an authorized administrator of PDXScholar. Please contact us if we can make this document more accessible: pdxscholar@pdx.edu. 
AN ABSTRACT OF THE THESIS OF Darcy Renée Murphey for the Master of Arts in Foreign Languages and Literatures: French presented on July 19, 1993.

Title: The Feminine Poetic Voice in the Rymes of Pernette du Guillet

APPROVED BY THE MEMBERS OF THE THESIS COMMITTEE:
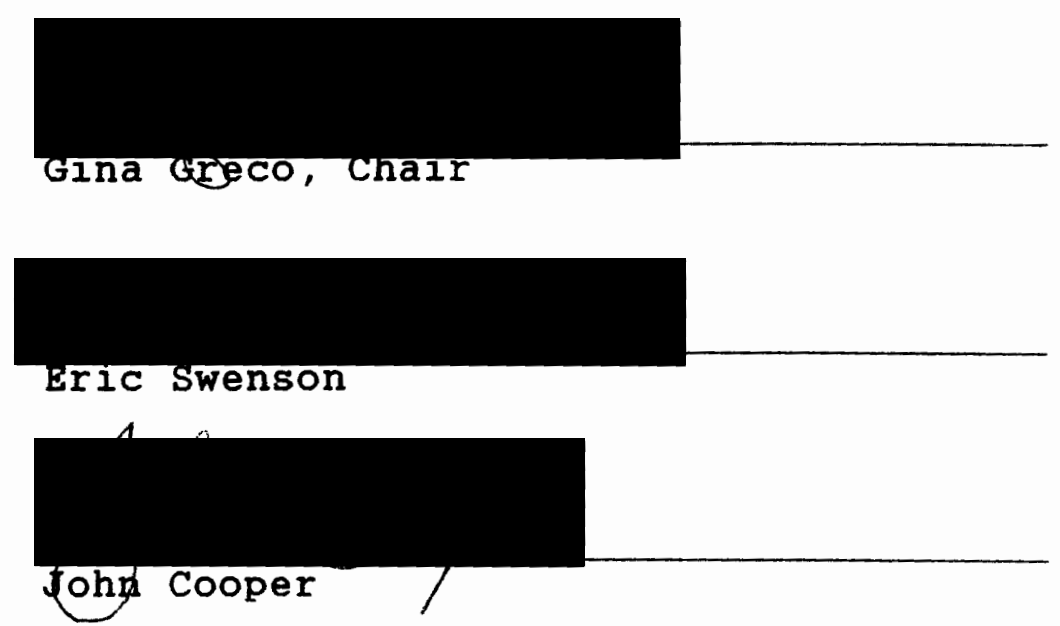

This thesis examines Pernette du Guillet's Rymes, focusing of her feminine poetic voice and her merit as a Neoplatonist Renaissance poet. In a time when literary endeavors were almost exclusively the domain of men, women presenting themselves as writers were often judged on the appropriateness of women writing as well as the quality of their work. Women had to forge their own identity as writers and find their own voice within a patriarchal society and literary community. 
The Introduction provides a social and literary framework for Pernette's work and presents pertinent ideas on using feminist literary criticism in the analysis of medieval and Renaissance literature. Modern criticism can often be a hindrance to unbiased reading of medieval and Renaissance literature when it is used to support modern concerns instead of illuminating the original value of these works. This Introduction offers some solutions to such a conflict. Renewed interest in women's work, for example, is one of the positive repercussions of feminist criticism. The literary canon is expanding to include more women as a result of feminist concerns. Feminism should not, however, negate the original value of a work because modern readers want to impose new interpretations over the original intent.

The first half of this thesis explores Pernette's Neoplatonism in contrast to the Petrarchism of her mentor, Maurice scève and the third member of L'Bcole Lyonnaise, Louise Labé. Pernette's association with Scève provides the necessary context for an examination of her poetry because their poetic correspondence and their romantic relationship provide many of the themes found in Rymes. This relationship also allows a comparison between Scève's poetry and the work of his student, Pernette, who develops into a mature poet during the course of her apprenticeship. Louise Labe's style offers a sharp contrast to Pernette's and Labé's means of establishing her feminine poetic voice furnish an essential 
comparison for comprehending Pernette's more subtle technique.

The second part of this thesis examines individual poems from Rymes, analyzing Pernette's choice of theme and her manipulation of vocabulary. Pernette's feminine poetic voice is a combination of the obvious grammatical manifestations of her female gender as well as the more subtle indications of the breadth of her voice. She demonstrates that she is aware of societal limitations, but refuses to let stereotypical roles dictate her poetic persona. Pernette uses her relationship to the more famous sceve in order to build a framework for her own work. Her adeptness as a poet lies in her ability to maintain her role as a lover and a student while conveying a proficiency that belies her reticent demeanor . 
THE FEMININE POETIC VOICE IN THE RYMES OF PERNETTE DU GUILLET

by

DARCY RENEE MURPHEY

A thesis submitted in partial fulfillment of the requirements for the degree of

\author{
MASTER OF ARTS \\ in \\ FOREIGN LANGUAGES AND LITERATURES: \\ FRENCH
}

Portland State University

1993 
TO THE OFFICE OF GRADUATE STUDIES:

The members of the Committee approve the thesis of Darcy Renée Murphey presented July 19, 1993.
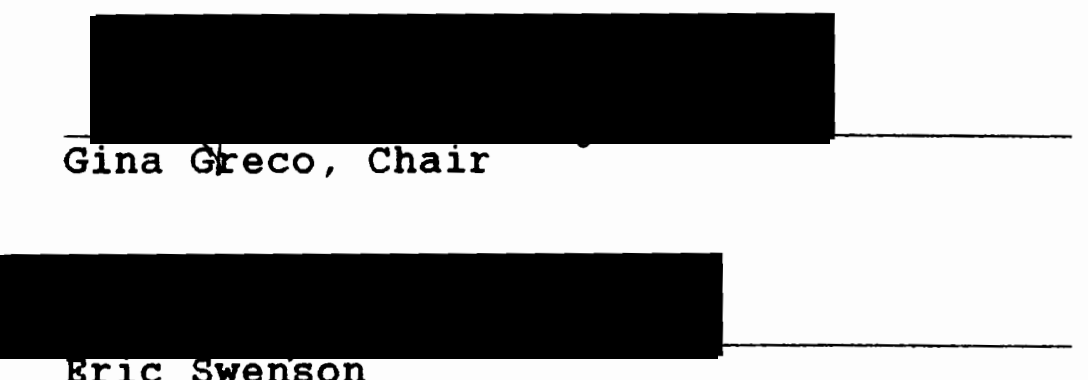

Bric swenson
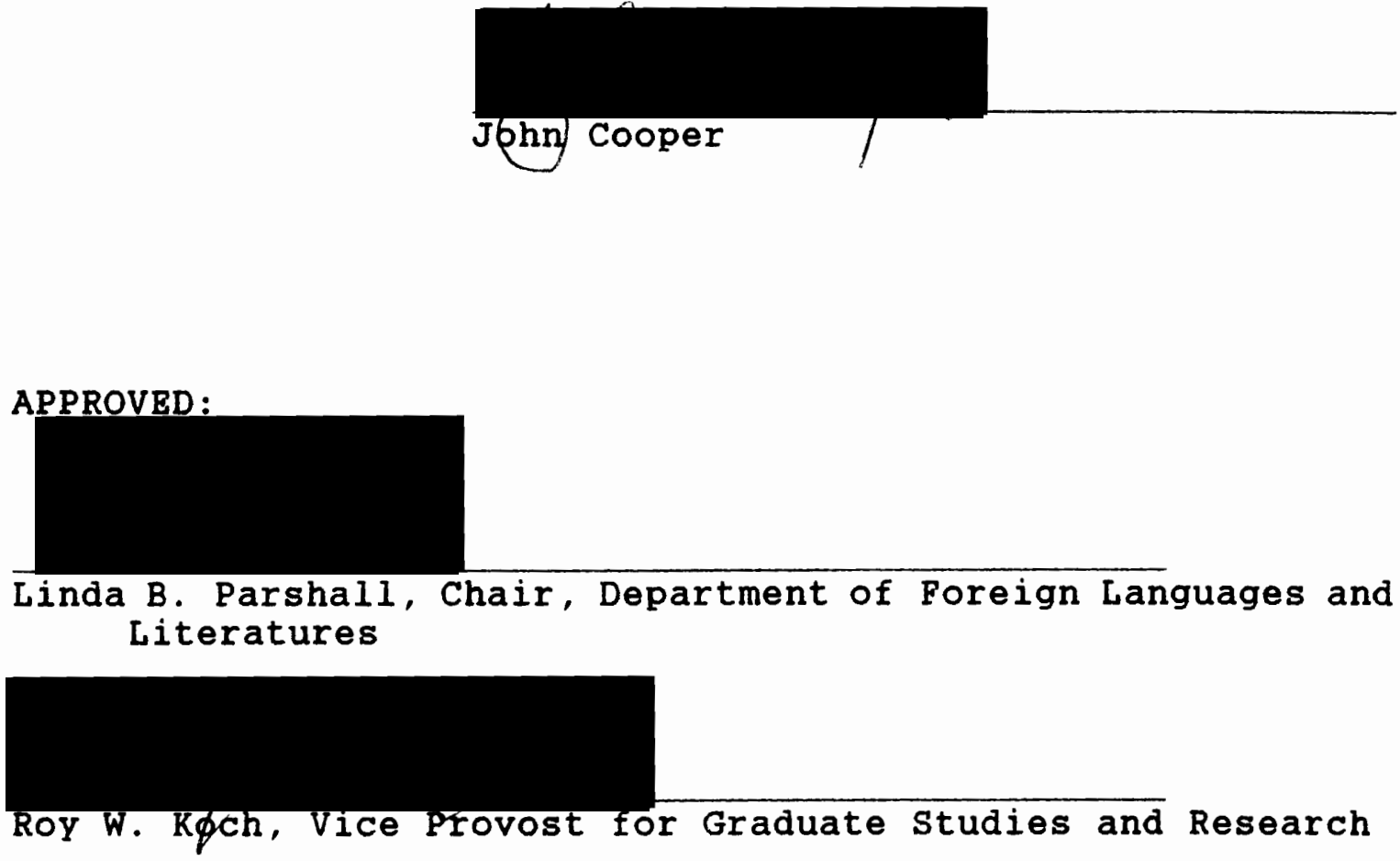
ACKNOWLEDGBMENTS

I would like to acknowledge and thank the people who have assisted in the successful completion of this project. I am grateful to my parents, David and Elaine sullivan, who have provided support in my academic career as well as continual faith in all of my endeavors. No less important is the understanding exhibited by my husband, Laine Murphey, during the months I spent in front of the computer. This thesis would not have been possible without his help and patience.

I am indebted to many people at portland state University. I owe many thanks to my thesis advisor, Dr. Gina Greco, for her invaluable help throughout the whole process, from the conception of the idea, through the research and the writing of my thesis. Her belief in the significance of $\mathrm{my}$ subject and her confidence in my ability were a constant source of support and inspiration. I thank Dr. Bric Swenson and Dr. John Cooper for their participation on my thesis committee and for their helpful suggestions on improving $m y$ work. Finally, I am grateful to the entire Prench faculty for their inexhaustible encouragement in my studies and their guidance in my teaching. 
TABLE OF CONTENTS

PAGE

ACRYOWL BDGBMENTS $\ldots \ldots \ldots \ldots \ldots \ldots \ldots \ldots \ldots$ ii

INTRODUCTION $\ldots \ldots \ldots \ldots \ldots \ldots \ldots \ldots \ldots \ldots \ldots \ldots \ldots$

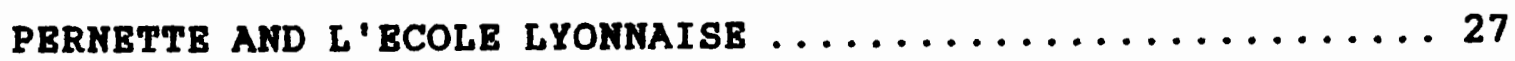

Maurice sceve ....................... 27

Louise Labe $\ldots \ldots \ldots \ldots \ldots \ldots \ldots \ldots \ldots \ldots \ldots \ldots \ldots \ldots$

A CLOSE READING OF RYMES $\ldots \ldots \ldots \ldots \ldots \ldots \ldots \ldots \ldots \ldots \ldots \ldots \ldots \ldots \ldots$

Theme and vocabulary $\ldots \ldots \ldots \ldots \ldots \ldots \ldots \ldots \ldots \ldots$

Poetic Merit ....................... 80

Conclusion $\ldots \ldots \ldots \ldots \ldots \ldots \ldots \ldots \ldots \ldots \ldots \ldots \ldots . \ldots \ldots$

WORKS CONSULTED $\ldots \ldots \ldots \ldots \ldots \ldots \ldots \ldots \ldots \ldots \ldots \ldots \ldots \ldots$ 


\section{INTRODUCTION}

This thesis is an analysis of the poetic voice of Pernette du Guillet in her sole volume of poetry, Rymes, as well as an exploration of her merit as the Neoplatonist member of L'Bcole Lyonnaise. In the predominately masculine literary community of the sixteenth century, women writers were forced to find their own voice within the confinements of a masculine poetic system. I will situate Pernette du Guillet inside this framework as well as examine the distinctiy feminine quality of her work.

Women writers who wished to be published were faced with two choices: they either worked inside the system subtly making changes from within, as in the case of Pernette, or they rebelled against the masculine strictures, forcing change from without, as did Louise Labé. I will first examine Pernette's Rymes against the backdrop of her role in L'Bcole Lyonnaise. Pernette's work is an extension of her relationship with her teacher, Maurice Sceve. Her Neoplatonism is a marked contrast to his Petrarchism and her poetry is an answer to his. Their poetic correspondence is the foundation of her Rymes. I will also relate her work to that of her contemporary, Labe, who rejects the dictates of the masculine literary commmunity and places her poetry on equal standing with that of her male contemporaries. The contrast between the 
two women's styles and philosophies adds an interesting dimension to the issue of female voice in the Renaissance because it will demonstrate that there is no one voice belonging to all women. Each writer, male or female, adds his/her particular mark to his/her work.

In this Introduction, I will present contemporary views on women's writing and feminism as well as a historical perspective of women in literature. The first part of this thesis will introduce Pernette du Guillet as both woman and poet. I will focus on her poetic relationship with Maurice Scève and how she metamorphoses from mere student and poetic object to a poet in her own right. Equally important is her status as a female poet in comparison to Louise Labé. I will contrast their styles and examine how their feminine voices both resemble and differ from each other. In addition, I will discuss the manners in which they establish their poetic identities. The second part will involve a close reading of Pernette's work, which has yet to receive detailed scholarly attention. Although a few scholars have referred to Pernette in their work, the treatment has been cursory and overly general. I will examine Pernette's choice of theme and vocabulary as well as her use of imagery in order to find her distinct voice. I will also discuss the poetic quality present in several of the more noteworthy poems from Rymes.

In her article "Petrarchan variations in Pernette du Guillet and Louige Labe," the feminist critic Gillian Jondorf 
analyzes the poetry of each woman and concludes that "... Pernette's neat verses seem rather strained and thin in comparison [to those of Labé]" (778). As is usually the case when these two women are compared, Louise Labe is judged to be a "foreward thinking poet" who is "ahead of her time," while Pernette du Guillet is relegated to a secondary position because her poetry is misread as little more than an imitative response to the poetry of Maurice Scève. Perhaps Jondorf's conclusion is based solely on the critic's personal preference. In my opinion, it also exemplifies the faulty assumption that Renaissance poetry read and critiqued by modern critics must somehow conform to twentieth-century criteria (such as our idea of gender roles and equality of the sexes). However, this need not be our sole point of reference. As a scholar, I am looking for new elements in the poetry of Pernette du Guillet. As a woman, I notice and want to highlight what I perceive to be the markedly feminine qualities of Pernette's work that are significant to the interpretation of her poetry. Nevertheless, I don't want to force this sixteenth-century work into a twentieth-century mold; rather, I want to help reveal the elements of her poetry that make it relevant and distinct in our modern literary world.

The concept of feminist criticism is relatively modern. It has only been in this century, especially the last twenty years, that an idea or necessity for a new critical approach 
to literary theory has been undertaken. With this new approach comes a new reading of old texts that may inadvertently discount the original value of the literature in a race to locate the seeds of our concept of feminist criticism.

In "Peminism as a Criterion of the Literary Critic," Margret Anderson discusses Adrienne Rich's concept of "revision," in which modern critics look at old texts with fresh eyes and from a new critical direction (7). Contemporary scholars are, in effect, re-reading the past, re-examining history from a new and particular point of view. Peminist critics are "reconceiving the nature of women in literature" (Jordan 75). As modern readers with this new point of view, it is conceivable that we might fall into the trap of misreading medieval and Renaissance texts with our own biases. Our current concerns and agendas color our interpretation of such works and we assign significance based on our own cultural reality.

Gillian Beer believes that this problem with interpretation stems from an "evolutionist model of literary development" (Representing Women 62). Modern readers are using the present as the ultimate reality against which all writing should be judged instead of trying to recreate the reality that existed for the original audience of a particular work. Even now, there is much disagreement on the direction and use of feminist criticism in the analysis of old texts. It is clear, however, that feminist criticism is an integral part of 
our reality and will be reflected in our modern analyses.

Margaret Atwood emphasizes the importance of literature in the history of a people when she says that "literature is not only a mirror; it is also a map, a geography of the mind" (Anderson 7-8). Consequently, as a result of our concerns with women's issues today, we can conclude that our exploration of the history of a people through their literature is incomplete if it includes no more than the history of men. Incorporating more women's literature into the canon is a valid modern concern brought to the forefront of literary criticism as a result of the evolution of feminine consciousness in the nineteenth and twentieth centuries.

Our literary tradition continues to be male-centered and biased in its view of women. Women's contributions to the field and their right to a place in literature seem to be negated by the relatively small number of women alloted positions in the prestigous partiarchal canon of literature. Yet our cultural heritage is enhanced by the perspectives provided by both men and women. Indeed, feminine consciousness is an effort to enrich the literary canon, not to supplant the biased partriarchal system with an equally one-sided matriarchal viewpoint. Women writers have silently co-existed with their male contemporaries, continuing to write despite the relative lack of acknowledgment of their work. Women have a place in literature that is theirs by virtue of their very existence. Our current historical perspective is deficient 
because it includes only the viewpoint of one half of the population; human experience is not limited to the male members of our society.

The canon of medieval and Renaissance literature includes but a few women writers. Students of medieval or Renaissance literature study the lais of Marie de France, assorted works of Christine de Pisan and perhaps the poetry of Louise Labé. When compared to the abundance of male-authored works that are studied and lauded, the number of women-authored texts deemed "worthwhile" is insignificant. We must concede that this is due in part to the fact that there are far fewer examples of women's work from which to choose. Due to the constraints imposed by their limited social positions, women did not participate in literary activities on the same scale that men did. Nevertheless, many women authors of merit have either been forgotten or excluded from the canon. In "The New Feminist Criticism," Annis Pratt asserts that feminist critics' first task in the revision of the canon is to locate and list feminist works (12). This introduces the problem of determining the distinction between the concepts of "feminist" and "feminine" literature.

Although we use the term "feminist" to define any number of women-related ideas, it is usually a label used to define those who battle for social and economic equality of the sexes in various political domains. It has acquired a negative connotation that equates "feminist" with "unfeminine" and is 
used to undermine the women's movement and all those who fight for equality.

The term "feminine" is a cultural imposition defining typical characteristics attributed to women in the same way that "masculine" denotes those characteristics that are viewed as belonging to men. "Feminine" is synonymous with "womanly" and "masculine" with "manly." Our society has judged feminine qualities to be inferior to masculine ones. For example, society usually frowns on men's work being labeled "feminine," and such an appellation is considered a slight. Indeed, society has applied different, but equally negative, connotations to each term. Por the sake of my discussion, "feminist" will denote "pro-women" stance and "feminine," an "of women" origin.

Xaviere Gauthier examines two divergent views on women's 1iterature in her piece "Is There such a Thing As Woman's Writing?" she describes the traditional definition of womenauthored literature as being "intuitive" or "sensitive," and embodying distinctly "feninine" qualities. of course, "feminine" is defined differently by different people as well as different cultures. These nebulous qualities are often products of the patriarchy and are frequently used to maintain the status guo in society; that is, to keep women in their proper place. In the same way that feminine qualities are seen to be inferior to masculine ones, the female point of view is considered 1 ess important than the male point of view. The 
other position Gauthier presents denies any difference between the sexes with regard to literature; according to this view, women participate in literature on the same level as men and there are no differences between their perspectives. Gauthier justly labels both opinions extreme in that they are both male-centered. In the first, women's work is judged by men to exude "feminine," or inferior, characteristics. In the second stance, women are performing at a "neutral" level, while still being rated against a norm: that is, men's performances. This second position is, in many ways, more demeaning to women than the first. It denies any difference between men and women and their perceptions of the world, implying that the historical exclusion of women from full participation in the realm of literature is due to some defect on their part, that their secondary position in literature is a result of their secondrate work. Gauthier closes with an image that is perhaps revealing of women writing and women's writing; according to her, women's writing encompasses:

... blank pages, gaps, borders, spaces and silence, holes in discourse: these women emphasize the aspect of feminine writing which is the most difficult to verbalize because it becomes compromised, rationalized, masculinized as it explains itself.... If the reader feels a bit disoriented in this new space, one which is obscure and silent, it proves perhaps, that it is women's space. (164)

Women writers in France have been exploring the question 
of women's literature and women writing for several decades. In a 1975 interview, Marguerite Duras gives her interpretation of feminine literature as "an organic, translated writing... translated from blackness, from darkness" (Marks 174). She believes that women have existed in darkness for centuries. When they write, they translate the darkness and begin to communicate in a new way, distinct from men. Mary Jacobus sees this separate language as an attempt to escape the Freudian definition of women as "non-maleness" rather than simply "Otherness" (52). In her article "The Laugh of the Medusa," Heldne Cixous seems to concur with this notion that feminine witing is a distinct literature with a separate voice and a particular language. She writes: "I write woman: woman must write woman and man, man..." (247); "...woman must write herself" (245). Cixous is saying that her writing stems from her being, and the inescapable fact is that she is a woman. Men and women are both biologically and psychologically different. Although Pernette du Guillet lived four centuries before Cixous penned these words, she too was cognizant of this phenomenon; she considered her words to be an extension of her very body. As I will demonstrate below, she offers her work for critique in much the same way that she might offer her body to a lover.

Clearly, we as twentieth-century scholars and historians examine and re-define women's place in society and literature every time we read. However, it cannot be assumed that 
medieval or Renaissance literature authored by women was a product of their feminism. sixteenth-century society cannot be judged and analyzed by our standards of what is "normative" today. For example, when scholars begin their analysis of Renaissance women with the question posed by Joan Kelly in her essay "Did Women Have a Renaissance?" and conclude, as did Relly, that the answer is no, they are buying into this theory of "Renaissance feminism." While it is true that Renaissance women experienced a tightening of legal and social constraints above and beyond medieval strictures, women did participate in the re-vitalization of the literary movement. They too experienced the re-invigoration of Renaissance art and literature as is clearly seen by the body of high-quality literature authored by women during this time.

In her article "gome Motes on Defining $A$ 'Peminist Literary Criticism," Annette Rolodny surmises that our problems with defining the goals and purpose of feminist criticism begin with the very term "feminist criticism." According to her, this blanket definition is used to describe three related but very different activities: 1) any criticism written by a women on any subject, 2) any criticism written by a woman critiquing a man's work from a political or feminist perspective, and 3 ) any criticism written by a woman on a woman's work or about fenale authors in general (37). Bach witer and literary critic defines feminist criticism from a slightly different point of view. However, in her reading of 
Josephine Donovan, Kolodny formulates a useful working definition of feminist criticism: "[it] is the commitment to discover what, if anything, makes women's writing different from men's" (40). Considering that much of women's work has been neglected and forgotten because it was authored by women who were considered socially and intellectually inferior, I believe that feminist critism should also include the commitment to give equal consideration to the work of women in the field of literature. Kolodny reminds her readers that it is important to keep in mind that feminine literature varies from writer to writer (41). For instance, the work of Pernette du Guillet can no more be "judged" against that of Louise Labé than it can be judged against some nebulous concept of modern feminism; each woman wrote in response to different circumstances and their work sprang out of differing experiences. On the one hand, their work can be read as parts of a whole tradition in women's literature; on the other, it can be compared so as to determine how two different women respond to partiarchal literary conventions to express their very different, but equally valuable, voices.

In order for such readings of Pernette and Louise Labé to be valid, we must first establish a context for each author. Indeed, when studying women's literature, I believe that an essential element of consideration is the historical context in which women both lived and worked. According to the feminist historian Joan Kelly, a woman's identity must first 
be defined in terms of the dominate sexual ideologies of the time in which she wrote. In addition, the women writers must be viewed within the context of the social, cultural, political and religious activities that helped define the role of women during the period in question (Rose, Introduction xiii). Situating the woman author in her own world is vital. Many modern French critics maintain that women have always rebelled against masculine discourse simply by virtue of the difference of their sex (Jones, "Assimilation" 136). Although a medieval or sixteenth-century woman's audience was frequently other women, it was characteristically a man who not only judged her work, but also furnished her with the literary model she used as an example. This question of women writers, their audiences, and their situations in a patriarchal literary world, can be more clearly understood through an investigation of the historical predicament in which educated women found themselves at the end of the Middle Ages and the beginning of the Renaissance.

Women have historically been confined to narrow categories. They participated in activities deemed suitable to their sex and social level. In The fourth sstate: A History of Women in the Middle Ages, Shulanith Shahar examines the role women played both privately and publicly in medieval society. She discusses their public and legal rights as well as explores the active role of women in the nobility, the church and towns. The narrow historical perception of women's 
public role is illustrated by Shahar's citation of the Bnglish jurist Glanville: "They [women] are not able, have no need to, and are not accustomed to serving their lord the king, either in the army or in any other royal service" (11). In effect, women were discouraged, and in many areas actually barred, from public office and service because they were thought to be unable to perform as effectively as men due to their physiological differences. Although there are examples of many women who held the strength behind powerful men, most women lived exclusively outside of the public realm. In legal matters a women's testimony was not even accepted without the substantiation of another witness. In theory, women had few rights apart from the legal protection of their bodies, but in practice, women could, and did, inherit property and all of the feudal rights and obligations that might have gone with it (Jordan 95). Nevertheless, all women experienced social and legal strictures to some degree.

Moblewomen and religious women were in many ways more fortunate because they had access to education, which was reserved for aristocrats and women destined for the church. Although noblewomen could not attend universities and were barred from pursuing most professions, they were educated, often in convents. Patricia Labalme asserts that a nobleman's daughter sometimes replaced a missing son in medieval society and was educated and reared to take his place (2). Joan Ferrante examines the education of medieval women in her 
article "The Bducation of Women in the Middle Ages in Theory, Fact, and Fantasy," pointing out that although women were receiving an education, there are few records that describe to what extent (11). Ferrante discusses several professions that were open to women like medicine (practiced by lay women) and, to a small degree, literature. She concludes that a good education did not guarantee equal opportunities for both men and women. Women writers did exist, but were limited in their choice of genre, subject, and audience. Many chose religious or spiritual subjects, adding to the collection of devotional literature comprised of saints' lives and descriptions of supernatural visions and revelations.

Love was, of course, another popular subject among women writers although it was by no means an exclusively feminine sphere. The fundamental difference between male- and femaleauthored works was that each sex brought differing perspectives to their work. They experienced life differently, which influenced their portrayal of love. This differing perspective is a meaningful ingredient in the study of literature from a woman's point of view. Women tended to depict their characters more naturally and honestly, relying less on stereotypes. Their female characters were often more realistic than those portrayed by male writers of the same period (Wilson Medieval Introduction $x x$ ). Their feminine perceptions offer another side of medieval life than that which male authors present. 
While it is true that medieval women did choose to write, they were caught between two opposing forces: women's traditional role battled with their desire for creative expression. Whereas it was deemed acceptable that a woman write to a female relative on private matters, a woman seeking a larger secular audience placed her reputation in question. Medieval and Renaissance women's roles were extremely fixed by legal and social restrictions. While male writers were experiencing a veritable renaissance of knowledge and art, women's social lives were being subjected to the tightening of rules and regulations. Their private roles became more rigidly defined than in previous centuries. In the late Middle Ages and early Renaissance, the schism between public and private functions became progressively wider (Wiesner 1-13). The women who did move beyond their traditional positions and who continued to write regardless of the repercussions in their personal lives provide a unique perspective on the life of medieval and Renaissance women.

Historically, women were defined in terms of their sexuality. Since they were frequently viewed as little more than sexual vessels, men were unwilling to accept any aspect of a woman's personality that diverted her from her "Godordained purpose": that of wife and mother. In Thinking about Women, Mary Bllmann gives an amusing and very telling account of male criticism of womens' work: "...books by women were treated as though they themselves were women, and criticism 
embarks, at its happiest, upon an intellectual measuring of bust and hips," almost as though "women wrote with breasts instead of pens" (30). The Bible was usually the "guide" for this sanctioned repression as it clearly indicated that women had no place in the public realm or in church leadership. Women were second-class citizens, functioning in closely supervised support roles.

In "A Room Not Their Own: Renaissance Women as Readers and Writers," Margaret Perguson explores the ways in which women have always been confined not only by societal rules but also by our cultural definition of woman. She contends that women are textually defined by men. The main problem that women writers encounter is that there is no escape from their society's definition of their sex (96). The fact that they are women is always foremost in their audience's mind. She discusses several texts in which medieval and Renaissance writers equate a woman's speech with her body, and thereby, her morality. Women were praised for their chastity and obedience, and of these, chastity was the most significant. It belonged first to her father and after marriage, to her husband. A woman's very body was not her own. Female silence was the outward manifestation of her virtue. Although there are many examples of men who were able to achieve great literary success despite a dissolute lifestyle, this was virtually impossible for a woman. Louise Labe's literary success and subsequent poor reputation attests to this. A 
women's profession could not be separated from her physical person and her ability to perform the duties for which she was "created." Women who continued to write and to participate in an overtly public life were continuously obligated to justify themselves before their masculine audience.

It was often the way in which a woman presented herself as a writer that dictated how she (and her work) would be received. The influential fifteenth-century poet Christine de Pisan, for example, was popular and lauded even during her lifetime. She was the first occidental woman to earn her living as a writer. Margret Anderson calls her the first woman writer to use feminist criticism in her writing (1). Christine ably demonstrated that a woman could be the literary equal of a man by virtue of her own talent, even without the aid of a famous male relative. Unlike Christine, other successful women writers of her time owed much of their fame to their family connections. Before she began her critique of the role of women in society, however, Christine demonstrated her mastery of literature and was thus able to gain acceptance through her broad knowledge.

Christine de Pisan is a good point of reference because she offers an exceptional portrait of her concept of femininity. According to her, a woman was not always the martyr of love or man's inferior (Wilson, Medieval Introduction xviii). She was very aware of the plight of women in her society and was interested in such themes as education 
and the problem of illiteracy, especially as they pertained to women. She also wrote about love in which women participated equally with men. Her themes are very personal and often geared specifically toward women. Among other subjects, she wrote about her happy marriage and the solitude of her widowhood: "Je ne sçay comment je dure/ Car mon dolent cuer font chanter d'iyre/... Ma dolente vie obscure rien, fors la mort ne desire/... Chanter que mon cuer soupire/...mais Dieux sçait ce que j'endure..." (Poesie Iyrique Rondeau).

Although her poetry was perhaps most pleasing to women, her technical skill rivals that of her male contemporaries. Privately, she conducted herself carefully and with much discretion. Her life was beyond reproach. Perhaps the work and person of Christine de Pisan were acceptable because she wrote first and foremost for women. She did not try to break down radically the barriers between the sexes. She worked from within the masculine system, arguing her case logically and systematically. Many of her ideas would not be considered "out-dated" in modern society. Nevertheless, although her morality was never questioned as was that of Lab6, and although her work was accorded enough importance by Jean de Meung to merit response, she was accused by many male contemporaries of being "misguided."

In works such as La Cite des Dames, perhaps the most important text in the querelle des femmes (Jordan 105), Christine explores the political and social causes of the 
negative attitude towards women. Her female characters refute the traditionally negative qualities attributed to then. Christine believed that women had been historically misrepresented. Consequently, history needed to be re-written in order to correct this false image (Jordan 113-114).

The literature of the day frequently described women as nothing more than temptresses and sorceresses. An anonymously authored popular book of the day entitled Les XV Joies, for example, posits that the negative portrayal of women is due to men's fear that women control reproduction. Men therefore represent women as shrews, spendthrifts, liars, whores, and so on, in order to rationalize their own fear of losing power (Jordan 87). Christine de Pisan eloquently refutes such notions in her letter "L'Bpitre au dieu d'amour," her response to Jean de Meung's Le roman de la rose. Jean's romance and Christine's subsequent letter revived the querelle des femmes in which various writers wrote either attacking or defending the "nature" of women. Jean's text depicts women as "sexually opportunistic and amoral" (Jordan 86). Christine's response is a thorough defense of honorable (her distinction) women. She offers no defense for the few who may be guilty of the indiscretions attributed to all women. In fact she questions the very existence of the multitude of these dishonorable women:

My answer is that women did not write these books, wherein can be read these slights on them and their 
morals. Those who plead their cause in the absence of an opponent can invent to their heart's content, can tell endless tales and keep the best parts for themselves, because aggressors have no qualms about attacking those who do not defend themselves. (Baird 37 )

Christine de Pisan also provides her own list of "feminine" qualities such as kindness and warmth, education and good sense, assigning the highest value to a woman's courage to develop God-given talents and pursue careers in social, political, economic, and literary fields (Wilson, Medieval Introduction xviii). The notion of God-given talents is important because, as God the creator imbues both man and woman with talents, it is logical that He expects both to exercise them.

As in the preceding centuries, women writers of the sixteenth century worked in a sphere almost exclusively dominated by men. scholars of medieval and Renaissance literature speculate that as soon as male writers began to invade the secular world, they appropriated the religous moralistic values from the church and imposed them on women. The pervasive attitude was that literary success on the part of a woman was linked to the absence of morality. In The Renaissance Notion of Women, Ian Maclean examines, in detail, the belief that a woman's body was tied to her psychology, thus rendering her invariably inferior to man. It was believed that a woman writer was unable to resist sexual temptations because her profession led directly to sin. In addition, since 
a virtuous woman found satisfaction in her domestic life (with either her father or husband), she had no need to look elsewhere for fulfillment. Furthermore, it was held that a woman writer thrust herself figuratively, and perhaps literally, among prostitutes. This theory has a long history and tradition. The idea that a woman's speech was equated with her virtue, or lack thereof, was the means of maintaining the status quo and the continued denigration of woman. In her preface to the account of the colloguium that asked the question "What is a Woman?", Evelyne Sullerot concedes that while there are obvious biological differences between men and women, the notion of the natural superiority of men and the consequent inferiority of women due to these differences is an imposed relationship. These terms are thus subjective cultural judgments (154).

In a similar vein to Maclean, Ann Jones outlines the basic arguments used to discourage sixteenth-century women against the literary profession in general in her article "Surprising Fame: Renaissance Gender Ideologies and Women's Lyric." She cites several works that explicitly identify the place of women in society. For example, In De studiis et literis Lionardo Bruini wrote that "rhetoric in all its formspublic discussion, forensic argument, logical fencing, and the like- lies absolutely outside the province of women." She quotes Thycidides as having often said that "the most praiseworthy woman is she whose praises are kept within the 
walls of the private house." Jones also quotes Aristotle's summation of a woman's place in society: "silence is the virtue of woman as eloquence is of man" ("Surprising Fame" 7579). These centuries-old arguments were continually used to insure that women remained confined to their well-defined roles. Although it was acceptable that a woman write to and for other women, she was not to present herself as man's equal, that is, as a professional writer writing for both men and women.

Christine de Pisan's work opened doors to the world of literature for the women writers who followed her. She laid the foundation upon which future women would build their own reputations as writers. Her literary example demonstrates that women are more than capable of an intellectual life. Pernette du Guillet's poetry doesn't spring full-grown from the mind of one young French woman who lived during the Renaissance. She profited from the groundwork laid by the women writers who preceded her. Indeed, each subsequent sucessful woman writer paved the way for women who followed.

Thus far in this Introduction I have attempted to situate Pernette in her historical movement, as a woman writing in the sixteenth century. This necessitated an evaluation of the notions of feminism and feminist, terms related both to women's writing and our perceptions of such writing. There is another aspect of Pernette's context that must be taken into account; that is, the specific literary context of forms, 
styles, and movements, as they pertain to the development of Pernette as a poet.

sixteenth-century love poetry evolved naturally out of pre-existing genres and forms practiced in preceding centuries. Humanism and Italianism re-invigorated the poetic tradition already in place, embellishing lyric poetry dedicated to courtly love. Renaissance poets were inspired by the poetry of Petrarch and the transcendental thought of Plato, making Petrarchism and Neoplatonism two of the most popular and pervading modes of lyric poetic discourse. Poets imitated and adorned the work of their predecessors while finding their own voice and style within the realm of traditional themes and genres. Contrary to being mere imitation, this was part of the evolving medieval literary tradition.

Gisele Mathieu-Castellani discusses the importance of well-defined Renaissance genres in her article "La Notion de genre." She maintains that clearly marked labels comprise a pact between the writer and his/her audience whereby the title acts as a virtual "pré-orientation" to the reading (29). In the case of Pernette du Guillet's Rymes, an anonymous editor considered this pre-orientation important enough that he gave titles to Pernette's individual poems in 1546 . Not only did this make the work more easily organized, it oriented Renaissance readers to Pernette's work.

Imitation and recognizable forms and techniques further 
facilitated reading on the part of the public as well as furnished writers with a framework within which they could expand their own ideas. The two poetic styles Neoplatonism and Petrarchism were philosophies that in many ways complemented each other while exploring differing aspects of poetic love. Neoplatonism, on the one hand, as understood and utilized by French Renaissance intellectuals, was an attempt to raise the level of poetry to a purer form. It built on plato's Dialogues, interpreted by Greek Platonists and subsequent Greek Neoplatonists, and focused on the aesthetic ideal of beauty as part of the divine harmonious cosmos. Poetry was viewed as a spiritual, transcendental activity, glorifying the pure aspects of a love unsullied by a baser sexual side, Love was a metaphysical absolute where concepts such as "la vertu," "le bien," and "l'amytie" were glorified above the physical expression of love, The extreme differences in focus between Neoplatonism and Petrarchism are very clear when the poetry of Maurice Scève and Pernette du Guillet are compared.

Renaissance poetry of the Petrarchan tradition, on the other hand, was defined first and foremost by its fidelity to Petrarch's love poetry celebrating Laura. The ideal of Renaissance beauty was a stylized image that had very little basis in reality. In her article "The Beauty of Women: Problems in the Rhetoric of Renaissance Portraiture," Elizabeth Cropper examines the connection between the Renaissance ideal of female beauty depicted on canvas and that 
same beauty glorified in poetry. She points out that sixteenth- century poets believed that it was impossible to capture the beloved's beauty on canvas. Poetry, however, could realize this ideal because the words created a stylized norm that surpassed reality, while maintaining an easily recognizable vocabulary.

In Petrarchan poetry the woman was present only as an idealized image, a stereotype. It was essential that there be poetic inspiration based on a feminine ideal. Bqually important was that this inspiration be both virtuous and indifferent towards the poet/lover. Her refusal was the basis for his suffering, which led to his poetic production and his love.

In Images littéraires de la femme à la Renaissance, Madeleine Lazard describes how women were perceived in the sixteenth century. She emphasizes the role of women as mere physical objects whose outward characteristics supposediy mirrored the inner person: "La beauté du corps n'est que le signe visible de la perfection morale de celle dont la vertu éleve le poète au-dessus des appétits charnels pour lui faire contempler le 'vrai bien'" (33).

Lazard stresses the necessity of the absent women in Petrarchan poetry. Not only is the woman/object's refusal necessary to the literary love relationship, the woman herself may be no more than a poetic convention. She ls simply the aesthetic pretext for the poet's creation. Lazard maintains 
that "ce n'est pas la femme qu'il aime, mais la fiction que ses vers ont fait naftre" (44). Of course, there are many instances where the inspiration behind the poetry was not a fictional creation, a mere literary convention, but a real woman. Nevertheless, it is the idealized woman and her symbolic representation that is critical to the Petrarchan poet.

The Petrarchan form poses obvious difficulties for a woman poet. In the next section, I will explore this question, among others, examining specifically Pernette's approach to the problem of expressing a woman's voice within the confines of Prench Renaissance poetic convention. 


\section{PERHBTTE AND L'BCOLE LYOMHAISB}

\section{MAURICE SCEVE}

It was not until the early twentieth century that the scholar Joseph Buche recognized Pernette du Guillet as the inspiration of Maurice Scève's Délie, published in 1544 (Graham Introduction xiv). This discovery provoked renewed interest in Pernette's Rymes. Hevertheless, Pernette's poetry remains virtually unexplored except as an extension of the work of Maurice Sceve. While the importance of sceve in the life and work of Pernette is irrefutable, her Rymes merit a more thorough exploration.

Although most of the details of Pernette du Guillet's life remain unclear, many of the dates of important events are known. What little information we have comes from Antoine du Moulin, publisher of the first edition of her Rymes. Born around 1520, she was aristocratic, albeit from the lesser nobility. Pernette was very well-educated, being an accomplished musician and linguist. She met scève in 1536 when he was already a well-known lyonnais Petrarchan poet. Scholars speculate that she presented herself to him as a prospective student. Whatever the circumstances of the initial relationship, they engaged in poetic correspondence that was to continue until Pernette's death in 1544, despite her 
marriage to the sieur du Guillet in 1537 or 1538. This was apparently not a love match since she had met and fallen in love with Maurice Sceve prior to her marriage. Most scholars contend that she remained physically faithful to her husband throughout her relationship with scève. However, there are no facts to support this hypothesis. Although Pernette's poetry seems to suggest that her lover/mentor and she engaged in a relationship that was based on shared intellectual interests, the ever-present theme of Neoplatonist love does not preclude the possibility of a physical relationship between Pernette and scève as well as an intellectual bond.

Their poetic correspondence is arresting because it places Pernette in the dual role of both inspiration of Delie and poet in her own right. This section of ny work will examine the many facets and implications of this relationship. I will discuss her imitation of sceve's style as well as their teacher/student relationship. I will also explore her metamorphosis from poetic object to poet.

The framework of the master/student relationship allowed student poets to find their voice within the realm of their teacher's poetry. Pernette du Guillet built her reputation and found her fame within the well-established reputation of her master. This was not an unusual phenomenon. The master's work was the point of reference and stylistic guide for learning. Ann Jones contends that the master/student relationship furthered the student's career because it implied a social 
bond between the two as well as demonstrating the student's familiarity with the work of the master (Eros 81).

As a student poet, Pernette used imitation to define and develop her own style. In the same way that sceve "read" Petrarch, Pernette "read" Scève (Boney 51). Many scholars remark on the imitative relationship between Pernette and Sceve and conclude that Pernette's work does not move beyond imitation because there are too many similarities between her poetry and that of her mentor. However, Pernette's response to the Petrarchism of Maurice Sceve was Neoplatonist. She did not violently abolish the role sceve created for her in Delie, rather, she assumed the role of Neoplatonist poet and participant in a pure love. Her Neoplatonism is her refusal to remain the simple Delie/object characterized in Scève's work as well as her opportunity for autonomy. As Ann Jones asserts in her analysis of Louise Labé and Pernette du Guillet, when Pernette chose Neoplatonism to voice her love, she was no longer the "transcendent ideal" captured in Delie ("Assimilation" 136). While it is true that she was no longer the silent unyielding object of love, she did not attempt to become the passionate lover/poet; Pernette created a new role for herself.

This charge of "imitation" could be leveled at sceve himself and any number of Renaissance poets who owed their style to the canzonieres of Petrarch. Renaissance poetry is the tradition of re-interpretation and the re-reading of well- 
known works. Moreover, a thorough reading of Pernette's Rymes shows that they are not mere stylistic or thematic borrowings from Délie. While her work is incontrovertibly linked to that of her mentor, it does not depend on the success of sceve for its merit.

Several of Pernette's poems contain direct references to the name Maurice Scève. Bpigram $V$ contains two anagrams of his name: "le VICB A SB MUBR" (line 2) and "CB VICE MUBRAs" (line 10). Significantly, her original poems did not capitalize upon these jeux de mots. Once the relationship and poetic correspondence between sceve and Pernette became known, subsequent editors began to highlight these phrases to take advantage of Pernette's relationship to the more famous scève. She also plays with the latin rendering of his last name in Bpigram XXXIV (line 1) and Chanson VI (line 34) with her use of the word "severe" [saevus]. Pernette's jeux de mots hint at a relationship behind her work that she never overtly reveals. Pernette states that she writes in order to glorify her master: "Preste moy donc ton eloquent sçavoir/ Pour te louer ainsi, que tu me loues" (Bpigram vI 11. 9-10). She indicates that his happiness, not her own fame, is her only goal: "Pour contenter celuy qui me tourmente/ Chercher ne veulx remede a mon tourment/ Car en mon mal voyant qu'il se contente/ Contente suis de son contentement (Bpigram XV). In her role as student, she does not offer her work as the equal of her master' 8 . 
While it is true that several of Pernette's poems are responses to DGlie or appear to mirror sceve's style and themes, similarities to her work can be found in Sceve's poetry. Bach writer responds to the other's work and both Delie and Rymes contain references to each other. I have chosen three poems that are usually cited to uphold the charge of "mere imitation" on the part of Pernette. I will examine each poem to determine the points of similarity as well as the differences.

scholars have noted the resemblance between Pernette's Epigran II and Sceve's dizain CCCLXVII. Both poens lament the absence of the "lover." Sceve writes: "Assez plu long qu'un siecle Platonique/ Me fut le mois que sans toi suis été" (11. 1-2). He is reinvigorated by the physical touch of his lover: "Sentant ses mains, mains célestement blanches/ avec leurs bras mortellement divins/L'un coronner mon col, l'autre mes hanches" (11, 8-10). As is typical in the poetry of sceve, his lover is epitomized by her sensual, tangible body. He describes his Delie in very erotic terms, focusing on her physical beauty and its effect on him. Pernette's poem is much 1088 erotic, but no 1088 effective. She treats the same theme in a very different manner.

Pernette writes that her loneliness is due to the appearance of night and the absence of day. For Pernette, her "Jour" is always scève. To continue this metaphor, "la nuict" is her separation from hili. The day is the scene of their 
"chaste amytie." I would argue that night is also analogous to her married life and the presence of her husband. She writes: "La nuite estoit pour moy si tresobscure/ Que Terre, et Ciel elle m'obscurissoit" ( 11. 1-2). She contrasts day with night, fear with joy, and sex with love. For Pernette, her love for Scève is not based on physical desire, but admiration and spiritual affinity. Whereas Scève notices his Délie's hands, Pernette is made whole again by the reappearance of the day, escape from the night and her duties as a married woman: "Mais quand je vis que l'aulbe apparoissoit/ En couleurs mille et diverse, et seraine/ Je me trouvay de liesse si pleine/ (Voyant desja la clarté la ronde)" (11. 5-8). She is relieved by his spiritual presence and he reacts to her physical being. Her vocabulary of restraint exhibits her mature attitude toward love. Her transformation of the same theme is not mimicry; she gives her own interpretation intimating her own virtuosity.

sceve considers the subject of "l'anneau" in dizains CCCXLVII and CCCXLIX. This second occurrence of parallel themes deals with the ring, the traditional symbol of love and the token exchanged by lovers to seal their vows. Sceve addresses both poems to the ring, not the woman: "Ta rondeur n'a aucun commencement/ Mi fin aussi, qui me donne a entendre/ Que captif suis sans élargissiment" (CCCXLviI 11. 8-10) and "Tu as, Anneau, tenu la main captivel Qui par le coeur me tient encor captif/ rouchant sa chair précieusement vive" 
(CCCXLIX 11. 1-3). He is captivated by the reminder of the relationship represented by the ring on the finger of his beloved. Once again, he focuses on the physical presence of his Délie. The presence of the object, the ring, leads to the contemplation of the woman wearing the ring.

Pernette, in counterdistinction, examines the ring from a psychological point of view. She sees the symbolic meaning behind the ring: "si tu ne veulx l'anneau tant estimer/ Que d'un baiser il te soit racheptable/ Tu ne doibs pas, au moins si peu 1'aymer" (Epigram X 11. 1-3). She is more concerned with the commitment represented by the symbolic object than the physical implications of the exchange of rings. She ends the poem with a reminder of the obligations that go along with the exchange of rings: "Pour te monstrer, que ne doibs oublier/ Comme tu fais, la sienne amour durable" (11. 9-10). Pernette's poem shows a depth of perception. She plays with Sceve's style so as to present both her superficial rendering of his theme as well as the deeper level of her understanding.

My third set of examples are obviously the product of an attempt by sceve and Pernette to treat the same subject using the same vocabulary and style. It is unfortunate that it is unknown which poem was composed first. It would be interesting to know if Sceve re-worked one of Pernette's poems or vice versa. Sceve writes in dizain CXXXVI:

L'heur de notre heur enflambant le désir Unit double ame en un meme pouvoir: 
L'une mourant vit du doux déplaisir

Qui l'autre vive a fait mort recevoir.

Dieu aveugle, tu nous a fait avoir,

Sans autrement ensemble consentir,

Bt posséder, sans nous en repentir,

Le bien du mal en effet désirable;

Pais que puissions aussi longtemps sentir

si doux mourrir en vie respirable.

Pernette's version is a huitain that transforms "1'heur de notre heur" into "l'heur de mon mal" in Epigram XIII:

L'heur de mon mal, enflammant le désir, Feit distiller deux cueurs on un debvoir:

Dont l'un est vif pour le doulx desplaisir,

Qui faict que Mort tient l'autre on son pouvoir.

Dieu aveuglé, tu nous as faict avoir

Du bien le mal on effect honnorable:

Pais donc aussi, que nous puissions avoir

8n noz espritz contentement durable.

Although the vocabulary of both poems is very similar, the effect is quite different. Pernette turns "the hour of our happiness" into "the hour of my unhappiness." Bach suggests the unity, or the presence of two lovers, but Sceve focuses on the sexual relationship while Pernette's poem seems almost accusatory: "Dont l'un est vif pour le doulx desplaisir." Scove, in contrast, writes, "L'une mourant vit du doux deplaisir." The woman in sceve's poem is in death's power and the male participant in Pernette's poem is the cause of her "desplaisir." In all, Pernette's poem seems to suggest that although there is always negative aspects present along with the good, there can ultimately be contentement, which is more 
durable than desire and passion. Scève views the "bien" as emanating from the "mal." He calls upon the passion as the mainstay of the relationship and, consequently, the future.

The poetic correspondence between Pernette and Scève is the product of what Ann Jones, as well as others, label the poetics of group identity. The poetic discourse is more than the dialogue between two people; it is a form of poetry aimed at an audience who act as invisible witnesses to the love recorded in the poems. Historically speaking, the relationship between Pernette and Scève is one of master to student. Scève was the established poet in Lyon and Pernette, his willing pupil. At another level, it is also a romantic relationship. Sceve's inspiration for Delie is his love for his muse, Pernette. Likewise, Pernette's poetry can be read as an outpouring of her affection for her mentor, sceve. However, the purpose of the poetic relationship is ultimately their poetry. Is this love a reality or a contrivance that makes each one's writing possible? Did each merely use the other as a sounding board and an excuse to write?

There is no question that he was, at least initially, her teacher. Pernette's Bpigram VII appears to have been written in response to a poen given to sceve to read upon which he made some sort of mark indicating a need for correction:

$R$, au dizain toute seule soubmise M'a a bon droict, en grand doubtance mise De mal, ou bien, que par $R$ on peult prendre. Car, pour errer, $R$ se peult comprendre. 
Signifiant que le $10 z$, qu'on me preste

Soit une erreur, ou que $R$ est riens, ou reste:

Mais $8 i$ par $R$ on veult responce avoir,

Je dy, combien que n'aye le sçavoir,

He les vertus que ton $R$ m'advoue,

Qu'errer je fais tout homme, qui me loue.

As is usually the case, Pernette reiterates that she cannot hope to aspire to the "sçavoir" or the "vertus" innate in her master and acknowledges her ignorance in comparison to sceve: "Par ce dizain clerement je m'accuse/ De ne sçavoir tes vertus honnorer" (Bpigram VI 11. 1-2). Much of the vocabulary in her poetry is dedicated to this subject: sceve as the source of all knowledge and Pernette as the dedicated, but unenlightened student. According to her, he illuminates her poetry as well as her spirit: "...par clarté adoulcie/ M'esclaire toute..." (Bpigram VIII 11. 5-6). In a similar vein, in Bpigram XX, Pernette clearly praises her teacher and lover: "Ton hault sçavoir, qui m'accroist l'esperance/ Des Cieulx promise, ainsi que je me fonde/ Que me feras avoir la congnoissance/ De ton esprit, qui esbahit le Monde" (11. 7-10).

In Epigram XXIII Pernette writes: "Je puis avoir failly par ignorance/ Cela me fault, maugré moy, confesser/ Mais que je prenne en moy telle arrogance/ Que dessus vous je m'osasse avancer" (11. 1-4), which is very suggestive in that it invites the reader to compare her poetry to that of her teacher. While claiming to be nothing more than a simple student with no hope of achieving the status of sceve, she covertly invites comparison between herself and sceve. 
Despite such occasional suggestive lines, Pernette praises sceve continuously. Some further examples are found in Bpigram III, in which she lauds his knowledge and calls him "1'excellence de toute grace exquise" (11, 2-3), and Bpigram IV, in which she continues her praise of Sceve as Apollo incarnate and thus worthy of his reputation and fame:

Bsprit celeste, et des Dieux transformé En corps mortel transmis en ce bas Monde A Apollo peulx estre conformé Pour la vertu, dont es la source, et l'onde. Ton eloquence, avecques ta faconde, Bt hault scavoir, auquel tu es appris, Demonstre assez le bien en toy compris: Car en doulceur ta plume tant fluante A merité d'emporter gloire, et prys, voyant ta veine en hault stille affluante.

Indeed, Pernette du Guillet goes out of her way to express verbally her humility and ignorance in comparison to Maurice Sceve. Her words indicate that she considers herself no more than an apprentice poet who stands in awe of the stature of her master. Mevertheless, she couches her humility in terms that lead her audience to consider her work as more than mere poetic exercises. She seems aware of the paradox between what she says and what she is, that is to say, a fine poet who was well aware of her merit as both poet and lover.

The romantic level of their relationship, as mentioned above, deserves further attention. Several of Pernette's poens indicate that she did have a real emotional attachment to her teacher. Likewise, if Scève's Dalie is any indication of his 
real feelings, the love expressed there was no 1888 a reality. Although their poetry was perhaps contrived for the pleasure of their audience, it does seem to stem from a real emotional love affair.

There is no doubt that much of Pernette's poetry is dedicated to her admiration for Maurice sceve. Written into this deep respect for his work is her love for the man. Although she writes about love as an ideal in the abstract, she also speaks directly to sceve about her feelings:

Prenez le cas que, comme je suis vostre

(Bt estre veulx) vous sopez tout moy:

Certainement par ce commun bien nostre

Vous me debvriez tel droict, que je vous doy.

Bt si Amour vouloit rompre sa LOY,

Il ne pourroit l'un de nous dispencer,

s'il ne vouloit contrevenir a soy,

Bt vous, et moY, et les Dieux offencer. (Bpigram XXVI)

She declares that she is his. However, "tout a moy" seems to indicate that she has rivals for his complete attention and, perhaps, affection. In this hypothetical situation where she is unreservedly his to love, he should honor her as she honors him: "Vous me debvriez tel droict." Pernette makes no attempt to hide the joy she experiences in the presence of her "Jour" as well as her displeasure at his attention to another woman who is undeserving of his love.

In Bpigram XXXI Pernette writes: "Je ne croy point ce que vous deites/ Que tant de bien me desiriez/ Comme a celle, pour qui vous feites/ Ce que pour vous faire debvriez" (11, 1-4). 
In this poem she compares herself to another, less worthy, contender for the love of sceve. Pernette considers herself the superior woman because she truly loves him but cannot express the depth of her feelings. Her rival's love is false because she speaks to flatter, not out of love. Epigram XXXII continues this contemplation of the unworthy rival who seeks to turn Scève's eyes away from Pernette, who genuinely loves him: "L'une vous ayme, et si ne peult sçavoir/ Qu'Amour luy soit ou propice, ou contraire/ $L$ 'autre envers vous faict si bien son debvoir/ Que plus ne sçait, où vous doibve complaire" (11. 1-4). She writes that she is unsure of his feelings toward her but once again, she leaves no doubt that her rival for his love is false. Pernette has a "cueur simplement nu," whereas her rival acts correctly but has no feeling behind her actions .

In some instances, Pernette states quite explicitly that she does love Scève as well as respect his "hault sçavoir." In Chanson IV she writes: "Ce que j'y suis tenue/ He me faict tant l'aymer/ Que sa vertu congneue/ Me contrainct l'estimer" (11. 19-22). Further along she describes her own feelings: "Ma fortune accomplie/ En mon heureux sejour/ De plaisir fut remplie/ Quand j'apperceu mon Jour" (11. 37-40), as well as labelling his love "noble amytie" (line 48). On the surface, her closing words serve to reinforce her continual abasement before the stature of her teacher. At a deeper level, it is a false modesty: 
Bt si je n'ay la grace

Pour meriter d'avoir

Ce bien, et qu'on pourchasse

De le me decevoir,

Ma femeté fera

Qu'il se contentera. (11. 55-60)

She says that her goal is simply to bring contentment to her teacher/lover; however, the fact that she has taken the time to use several of her poems as a forum in which she compares herself to her rival indicates that she considers herself, and by extension her poetry, worthy of consideration. "Bt si je n'ay la grace" is not her excuse for not being able to measure up to her lover's stature. Rather, it is her way of bowing to those who might seek to criticize her poetry. If her ultimate goal is not to prove herself a better poet than her master, but to please him, no one can criticize her work as inferior.

Bpigram XXVIII is very interesting in this light in that it straddles the line between the master/student relationship and the lover/lover relationship:

Si je ne suis telle que soulois estre, Prenez vous en au temps, qui m'appris Qu'en me traictant rudement, comme maistre, Jamais sur moy ne gaignerez le prys.

Bt toutesfois, vous voyant tousjours pris

Bn mon endroit, vostre ardeur me convye

Par ce hault bien, que de vous j'ay compris,

A demeurer vostre toute ma vie.

In Pernette's response to Sceve's correction of one of her poems (Bpigram VII), she does not complain about his right to 
teach her and to correct her work. This poen was evidently written at a different stage in their relationship. At this point, she reacts to his role as teacher ostensibly because they had moved beyond the master/student relationship into more emotional territory-that of love. At first she says that she will deny him her love as a result of his uncalled-for treatment: "Jamais sur moy ne gaigneriez le prys" (line 4). By the end of the poem, however, she has left her anger behind and admits that his "ardeur" convinces her that his love is not false. She does not reject his love but rather decides, "A demeurer vostre toute ma vie" (line 8 ).

At the same time that Pernette is sceve's student and lover, she is also the source of inspiration for his poetry and the object of his desire, his Dblie. There are no pictures of Pernette to indicate whether or not she was beautiful, but many scholars cite Sceve's dizain CCLXCVI as the "evidence" that Pernette was blond. "Tes cheveux d'or annelés et errants/ si gentiment dessus ton soleil dextre..." Although it is possible that she was indeed blond, it is more likely that scève described his Délie in the usual terns of a Petrarchan poet. In another example he writes: "Amour, lustrant tes sourcils ebenins..." (dizain CCLXX). Pernette, the wowan, is present as poetic inspiration, not as a living, breathing being.

He uses extremely passionate terms to talk about his love and the effect she has on him in dizain XCVI: 
Te voyant rire avecque si grand' grace,

Ce doux souris me donne espoir de vie,

Bt la douceur de cette tienne face

Me promet mieux de ce dont $j$ 'ai envie.

Mais la froideur de ton coeur me convie

A désespoir, mon dessein dissipant,

Me remet sus le désir qui me mord.

Parquoi tu peux, mon bien anticipant,

En un moment me donne vie et mort.

The real woman, Pernette du Guillet, is not the woman presented in D61io. She is obviously more than the student sceve corrects and teaches. Her most important role is that of poet. She moves beyond her role of student and object to become the creator, not the created. No longer defined in male terms, she defines herself and creates her own poetic reality. Her changing identity incorporates and reflects each of the previous roles assigned to her. The woman sceve illustrates in Delie is clearly not regarded as an equal in the partnership of love; the Petrarchan lady never is. He defines Pernette by the physical. He does not write to her as a poet but rather as the recipient of his love. Her own poems pay tribute to the greatness of her mentor, but she does not attempt to duplicate his style.

\section{LOUISE LABE}

I have previously discussed the historical relationship between how a woman writer presented herself and the subsequent reception of her work. In the case of the lyonnais women writers, Pernette du Guillet and Louise Labé, the manner 
in which the writer and her work were presented did affect the way that contemporaries viewed each poet's work. Bach women's social position contributed to her subsequent success and reputation. In effect, the personal history and writing style employed by each woman helped to mold the way that the public perceived her. Labé's Petrarchism seems to indicate an outgrowth of her passionate nature in the same way that Pernette's Neoplatonism might indicate the manifestation of her more restrained love and personality. Textually, Labés work demonstrates an outward rebellion against the conventions of the masculine literary world, while Pernette's poetry works within the system. The latter quietly builds her own reputation within the bounds or the reputation of her mentor, Sceve. As the other female member of the Bcole Lyonnaise, Louise Labé provides an interesting context and comparison for understanding the more subtle poetic style of Pernette du Guillet.

Louise Labe remains the better known of these two women writers for a variety of reasons. Her poetry was dynamic and ground-breaking in sixteenth-century France. In addition, her poetry remains very accessible to modern audience. She was a prominent member of the literary community who promoted her poetry and her image as a poet during her lifetime. Although she wrote within a Petrarchan form, her work is far from identical to that of her male contemporaries. Some scholars critique her work as being too close to that of Petrarch. 
However, as is the case with Pernette du Guillet, Labe, the poet, breaks out of the traditional female role assigned to her in Petrarchan poetry and transforms the traditional into something new. No longer the disdainful uninterested female object, these women become both lover and poet. Their feminine voices transpose the images they evoke and the symbols they utilize. Labe is always aware of herself as a woman in love in her poetry. Within the confines of the genre she transfigures Petrarchan poetry, whereas Pernette's Neoplatonism leaves Petrarchism unchanged as it allows her to create a different poetic persona.

Labe plays with a masculine-dominated genre to create a poetry that speaks with her own voice. She adapts the Petrarchan tradition to her own reality. When she laments the absence of her lover in the Petrarchan mode, she does so without rendering her lover ridiculously soft and womanly. Whereas women were simply objects to love, they now appear as the aggressors in love, taking responsibility for their own passions. Her sonnets are as passionate as those of her male contemporaries. Louise Labe takes on the active role of lover and relegates the male to the passive, absent role of lover/object: "Ou es tu donq, o ame bien aymee?" (Sonnet VII). The vocabulary is extremely ardent, encompassing the extremes of love. Labe describes the unrestrained passion and desire of her love. Sonnet III is particularly descriptive of the Petrarchan theme of the suffering and anguish of love. The 
vocabulary is also typically Petrarchan:

- longs desirs, 6 esperances vaines, Tristes soupirs et larmes coutumieres $A$ engendrer de moy maintes rivieres, Dont mes deus yeus sont sources et fontaines:

O cruautez, 0 durtez inhumaines, Piteus regars des celestes lumieres: Du coeur transi 8 passions premieres, Bstimez vous croitre encore mes peines?

Qu'encor Amour su moy son arc essaie, Que nouveaus feus me gette et nouveaus dars: Qu'il se despite, et pis qu'il pourra face:

Car je suis tant navree en toutes pars, Que plus en moy une nouvelle plaie, Pour m'empirer ne pourroit trouver place.

This poem extinguishes any lingering doubts that women do not participate actively in love. The fact that she has assumed the role of lover reverses the typical image of feminine subservience and establishes a new ideal of woman's place in poetry.

Louise Labe's personal history is certainly a contributing factor to her revolutionary success as a Petrarchan poet. She was a product of the middle class, being both the daughter and the wife of rope makers. She was born somewhere between 1516 and 1523 , making her several years Pernette du Guillet's senior. On the one hand, some scholars give her bourgeois origins as the reason that she was able to effect change in the literary world; while on the other, the scholar Fernand zamaron argues that some of the disapproval 
aimed towards her and her subsequent poor reputation stem from her humble origins. As she courted the aristocracy, she snubbed her own people: the bourgeoisie. Indeed, Ann Jones contends that much of the animosity toward her may very well be a result of the hostility toward her social climbing ("City Women" 302).

It is significant to note that she applied to the king and was granted permission to publish her own work. Not only was this very uncommon, but it is certainly one of the factors that contributed to her poor reputation, both during her lifetime and after. Instead of waiting for a patron's pleasure to sponsor her work, she presented herself on equal level with the male poets of the day. By including the work of others written in her honor in her volume of poens, she confirmed the breadth of her fame. Combined with the fact that she was a married woman who enjoyed the company of many male friends, some of whom may have been lovers, her audacity in publishing her own work made her immediately suspect in the eyes of the world.

Regardless of her questionable "virtue," there is no argument as to the quality of her poetry. As stated above, it is Petrarchan, but with one very significant difference: she is the impassioned lover, not the disinterested female object. When a woman takes on the role of poet, she finds herself outside all that is traditional because she is no longer an object of desire. As has been demonstrated, the Petrarchan 
poet traditionally found his inspiration in the theme of female disinterest and absence. It is a poetry of despair, anguish, and ultimately of hope. When the woman is the poet, she upsets the status quo. It is rather ludicrous to imagine the male cast in the role of the disdainful, virtuous object of love. Labe doesn't attempt to cast her lover in the role that she has vacated. Instead she creates a new role for him: that of the unfaithful, neglectful lover. Her suffering and inspiration stems from his negligence.

Louise Labe reverses the roles in her poetry. Thus although her work is Petrarchan in its themes and vocabulary, it expresses a noticeably feminine point of view. She employs an extremely sensual vocabulary expressing a woman's active participation in love, "Je suis le corps, toy la meilleure part" (Sonnet VII). Labe's plays with the feminine/masculine aspects of the French language. She chooses the feminine "la meilleure part" to indicate her lover, which demonstrates the reversal of their roles due to her activity as poet. Purthermore, she is not afraid to let the world know, in explicit terms, that she too experiences the passion of love:

Baise m'encor, rebaise moy et baise:

Donne $m$ 'en un de tes plus savoureus,

Donne m'en un de tes plus amoureus:

Je t'en rendray quatre plus chaus que braise.

-..

Jouissons nous l'un de l'autre notre aise. (Sonnet XVIII 11. 1-4, 8) 
Sonnet XXIV is full of very sensual imagery:

Ne reprenez, Dames, si j'ay aymé

Si j'ay senti mile torches ardentes,

Mile travaus, mile douleurs mordentes:

Si en pleurant, j'ay mon tems consumé. (11. 1-4)

One of the most telling manifestations of Labe's feminine voice is her manipulation of the gender of the word "love." Prançois Rigolot has written extensively on her transformation of love's gender. He maintains that this manipulation is a clear mark of her role as a woman poet ("Gender v8. Sexual Difference" 290-291). Labé modifies the word "love" to suit her needs. During the Renaissance, the word "amour" denoting the abstract concept of love was feminine and the god "Amour," or Cupid, was masculine. Nevertheless, Labé writes: "...ne vivant pas, mais mourant d'une Amour/ Leguel m'occit dix mile fois le jour" (Elegy II, emphasis mine). "Amour" is first feminine here and the context leads the reader to assume that she is not referring to the god, although she deliberately allows the ambiguity with the second masculine reference. The association with the masculine god Amour makes the reading of "Lequel" more clear. The relative pronoun "Lequel" is masculine and yet it refers back to the feminine "Amour." In this case, Labe plays with the gender in order to indicate that her lover is the masculine object representing "Amour," the concept. Her suffering is due to love and her lover's neglect; they are one and the same. Her lover is the object of 
her desire and he is the living embodiment of "Amour."

This duality of Amour/amour is reinforced by her reference to the god in Sonnet IV: "Depuis qu'Amour cruel empoisonna/ Premierement de son feu ma poitrine...". She is able to further strengthen the relational identification between her three definitions of love, that is: the god, the abstract concept, and her lover. This sonnet describes the anguish associated with Cupid's arrows of love. Her pain is physical as well as emotional. All three definitions work together to form one manifestation of love that Labe uses to convey her feminine interpretation of Petrarchism.

This Petrarchan genre of poetry poses an obvious problem for a woman poet. She cannot be both idealized image and ardent suffering poet simultaneously. Purthermore, male poets drew upon a poetic language based on a long tradition. For example, the blasons represent a privileged form of the description of feminine beauty. The female poet, however, had no such guide in the description of masculine beauty. Louise Labe forged her own way as both Petrarchan lover and created her own vocabulary of love.

Both Louise Labe and Pernette du Guillet took these traditional models and transformed them. They worked within the classic forms and added their personal marks, which I maintain are recognizably different from those of their male contemporaries. In fact, Labe does describe the "beauty" of her lover in sonnets II and $X$ : "O yous bruns, 8 regars 
destournez" (Sonnet II) and "Quand $j$ 'aperçoY ton blond chef couronne" (Sonnet $X$ ), but she plays with the traditional blasons to create a stylized description of her own. Instead of the "hair of gold" and the blue eyes attributed to an ideal woman created by the poet, she creates her own standards of male perfection. Pernette does not attempt to describe her lover's physical appearance in her work. Instead she chooses to focus on his intellect, which, for her, is the more important of the two.

Among the first obstacles that a female poet encounters is one of poetic inspiration. As both Labe and Pernette begin with traditional discourse and then move beyond it, they must find their place as women in their poetry, while creating a place for themselves as poet. Apollo is traditionally considered to be the god associated with art and poetry as well as the very reflection of the poet. As there is an identification between the male poet and Apollo, a woman poet cannot present herself as the incarnation of Apollo. Joann Delaneva has fustly remarked that this would render the image of Apollo effeminate. Likewise, it is the female Muses who bestow the gift of poetry and are the sources of poetic inspiration. How can a woman poet love and serve the Muses as Apollo incarnate without putting her sexual identity into question?

Louise Labe solves this problem by choosing Sappho, a classical female poet from the isle of Lesbos, as her poetic 
model and Apollo as her inspiration:

...Chanter me fait, non les bruians tonnerres

De Jupiter, ou les cruelles guerres,

Dont trouble Mars, quand il veut, l'Univers

Il 'a donné la lyre, qui les vers

Souloit chanter de I'Amour Lesbienne'... (Blegy I 11. 11-15)

Labe mentions the lyre, which is associated with Apollo and poetry, thereby demonstrating that she will accept traditional poetic conventions that designate Apollo as the inspiration of poetry. At the same time she will follow sappho's poetic example, creating her own identity as a female poet.

Pernette du Guillet does not break completely with tradition in her choice of inspiration. Apollo, "le Dieu du soleil," is the source of her inspiration and illumination. His earthly counterpart, or incarnation, Maurice Sceve, is the source of her poetry: "Comme mon Jour, il peult partout aller/ Par une mode au Soleil coustumiere... Car de ses rayz toutes faict lumiere...Plus elle est noire, et plus fort il reluict" (Bpigram XXXIX 11, 1-2, 5, 8). Pernette praises Scève by comparing him to Apollo: "Bsprit celeste, et des Dieux transforme/ En corps mortel transmis en ce bas Monde/ A Apollo peult estre conformé/ Pour la vertu, dont es la source" (Epigram IV 11. 1-4). He is her "Jour au Monde" (Bpigram II).

1 The word "Lesbienne" refers to the inhabitants of Lesbos. It has no homosexual connotations at this time. 
She states very clearly in Blegy II that as a poet, she is subject to Apollo and the Muses:

...Mais, pour me veoir contente a mon desir, vouldrois je bien faire un tel deplaisir

A Apollo, et aussi a 808 Muses,

De les laisser privés, et confuses

D'un, qui les poult toutes servir à gré,

Et faire honneur a leur hault choeur gacré?

Ostez, ostez, mes souhaitz, si hault poinct

D'avecques vous: il ne $m$ 'appartient point.

Laissez le aller les neufs Muses servir,

Sans se vouloir dessoubz moy asservir,

Soubz moy, qui suis sans grace, et sans merite.

Laissez le aller, qu'Apollo je ne irrite,

Le remplissant de Deite profonde,

Pour contre moy susciter tout le Monde,

Lequel un jour par ses escriptz s'attend

D'estre avec moy et heureux, et content. (11. 39-54)

Pernette aspires to the heights of sceve and is inspired through him by Apollo. She refuses the right to be directly responsible to either the Muses or Apollo because of her lack of knowledge. Her mentor acts as the intercessor between Pernette and poetic inspiration. His success is her shared glory in the poetic act of creation.

The poetic construct for inspiration is not the only point on which the two women differ. Louise labe was a wellknown poet during her lifetime, whereas Pernette's Rymes remained relatively unknown until after her death. Although scholars have found evidence that several of Pernette's poems had previously been published as songs and that she had probably recited selections of her poetry in select company, it was only after her death that her husband urged Jean de 
Tournes to publish her Rymes. Louise Labé reveled in her own participation in the literary community in Lyon, while Pernette and her work remained relatively outside of the literary community during her lifetime.

The dedication of her volume was written by Antoine du Moulin, a noted sixteenth-century editor and, incidently, valet de chambre to Marguerite de Navarre. He dedicated the work to the "Dames Lyonnoizes." In doing so, he was classifying the volume as women's literature, while still making it available to the general public. His insistence on the positive influence of her poetry on women removes any doubt as to the nature of Pernette herself. Antoine's dedication furnishes a circumspect portrait of Pernette as both woman and writer. He emphasized her feminine qualities, "...vertueuse, gentile, et toute spirituelle Dame D. Pernette du Guillet..." (Graham 2). This served to make Pernette "suitable" feminine reading at the same time that it insured the protection of Pernette's reputation.

As it was a man publishing a woman's posthumous work expressiy for other women, her reputation seems to have suffered little. Jan Boney maintains that it was due to the "perceived chastity" of Pernette that her work was even published (59). In keeping with this idea, Antoine concentrates his praise on Pernette's positive womanly attributes, not the poetic quality of her Rymes. He focuses on the worthy nature of the poet, highlighting the pure nature of 
the woman. He praises the "dexterité de son divan esprit" (Graham 2) as well as her education and refinement. He described her writing as "le chemin bien" (3), undertaken expressly as the guide for other virtuous women: "Bt quand ce ne seroit, qu'elles pourront inciter quelqune de vous, ou d'ailleurs et l'animer aux lettres, pour participer de ce grand et immortel los ..." (3). Antoine quietly introduces the Rymes as quality feminine reading, suitable in every way as a model for other "worthy" virtuous women.

When compared with Labe's own epitre dedicatoire, the diametrically opposed purposes become very clear. Labé dedicates her work to a woman of the nobility, Mademoiselle clémence de Bourges. In traditional male-authored poetry, this type of dedication is completely natural. Men addressed their work to prominent women in order to flatter them and to reinforce the prevailing male/ female stereotypes of the day. Men were the creators, writing in praise of women's "female" qualities, while women were, in effect, the created. They were defined in terms of men's representation of them. Louise Labe's epitre focuses on some of the same women's issues that Christine de Pisan wrote about more than a century before. Labe dedicates her work to a woman in an attempt to change the status quo. She is rebelling against the notion that woman is the object who receives praise from the male. In dedicating her work to a noblewoman, she is bringing all women up to her level, making all women partners in a shared poetic 
experience. The woman to whom the work is dedicated is a participant in the poetry, not an object or "occasion for poetic expression." Labe is urging women to follow her example and take their lives, and perhaps their destinies, into their own hands.

Labe does not completely dismantle the framework of traditional roles to make her point, instead she works within the bounds of her chosen genre to create a more reasonable feminine role. She explains her purpose in both writing and publishing her work to Clémence de Bourges, while taking advantage of her epitre as an arena for social commentary. In fact, she says that she had no intention of having her work published, she wrote solely to please herself and to take advantage of the talents that she possessed:

Mais depuis que quelcuns de mes amis ont trouve moyen de les lire sans que j'en susse rien, et que... ils m'ont fait à croire que les devois mettre en lumiere: je ne les ay ose esconduire, les menassant ce pendant de leur faire boire la moitié de la honte qui en proviendroit. Bt pource que les femmes ne se montrent volontiers en publiq seules, je vous ay choisie pour me servir de guide... (43)

She displays a humility that was virtually obligatory at this time. Poets were compelled to present themselves as humble artists when offering their work. Labe knows that she has something to offer, but she presents herself as a reticent poetess, reserved and disinclined to impose her voice. However, at the same time she says that women are obligated to 
follow an intellectual or artistic path if they possess talent in that area:

...celles qui ont la commodité, doivent employer cette honneste liberté que notre sexe ha autre fois tant desiree, a icelles aprendre: et montrer aus hommes le tout qu'ils nous faisoient en nous privant du bien et de 1 'honneur qui nous en pouvoit venir... (41)

She reiterates the same urgency that Christine de Pisan exemplified in the previous century; women have much to offer and it is their duty to live up to their potential.

Louise Labe had an advantage over Pernette du Guillet in that she lived to see her work published. Through the dedication, Labe forged her own creative future in publishing her work herself. She was able to make a statement with her work that Pernette could not. Whereas Pernette's work is as textually rich as that of Labe, the "feminist" aspect and purpose of Labe's work are much more pronounced than anything in Rymes. Perhaps most evident in the work of Labe is her identification with her female audience.

Labe addresses her work to a woman and she places herself among all women in much of her poetry. She addresses women directly in several of her poems: "Dames, qui les lirez" (éptre dedicatoire 43), "Quand vous lirez, O Dames Lionoises" (Elegy III line 1), and "Ne reprenez, Dames si j'ay ayme" (Sonnet XXIV line 1). Purthermore, she consciously places herself in the community of Lyon every time that she uses the 
name "Lionoise." She identifies herself with "everywoman" and with her community, Lyon. Antoine du Moulin obviously knew the importance of origin because he too underlines the fact that Pernette du Guillet was a lyonnais poet. Renaissance Lyon was an important literary and artistic city due to its proximity to Italy, where the Renaissance originated before it found its way to France. All things Italian were popular and, in many instances, thought to be superior to their French equivalents. In addition, Lyon was located outside the sphere of royal control far from the royal eye, being located far from Paris. Lyon, and its Bcole Lyonnaise, were at the forefront of Prench literature and art. When Labé and Antoine du Moulin insisted upon the lyonnais origins of the poetry in question, they were in fact lauding its superiority to anything that may have been coming out of other parts of France, as well as its kinship to Italy's best literary offerings. In fact, both Pernette and Louise Labé composed poems in Italian. Both women were welleducated and at the forefront of France's literary renaissance.

Pernette also chooses to talk directly to women in one of her poems. She places herself on equal terms with all women when she uses the pronoun "nous" throughout Chanson V:

\footnotetext{
Dames, s'il est permis

Que 1 'amour appetisse

Bntre deux cueurs promis,

Gaisons pareil office:

Lors la legerete

Prendra sa fermet.
} 


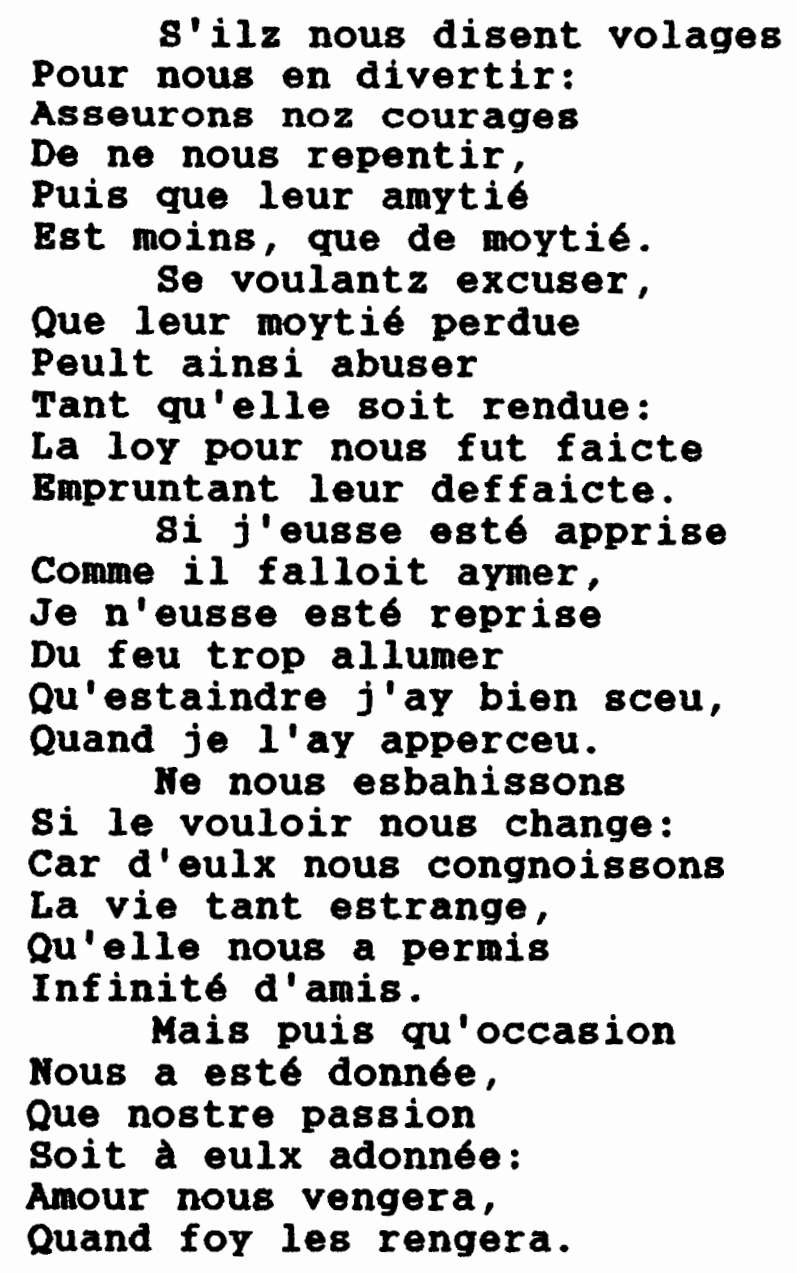

While this is perhaps not Pernette's most striking Chanson, it is interesting due to its call to women. Both Pernette and Labé- although Pernette less consistently that Labé- try to place themselves among women, claiming kinship to all womanhood and expressing a woman's point of view in the game of love. They offer their decidedly feminine view of the world, love, and woman's place in the world.

Both of these women achieve similar results by different. means. They establish their poetic identities by following different ideologies. Labe answers Petrarchism with her own 
version of Petrarchan poetry. She molds the genre to her own needs. Pernette's poetic philosophy is quite different. Her poetry is a response to a particular Petrarchan poet who is both lover and teacher. As has been shown, she answers his Petrarchism with a Neoplatonist voice. In Elegy I, one of her deepest reflections on the nature of love, Pernette lauds, quite explicitly, the true lover's restraint and affection in the face of more worldly examples of love. In a similar vein, she praises the Neoplatonist ideals of "la vertu" in Bpigram XLII: "Car la vertu est d'une action lente/ Qui tant plus va, plus vient a se nourrir" (11, 3-4). In Bpigram XLIII love is "un contentement/ Qui faict sentir, et veoir ce bien durable" (11. 2-3). She does not negate Sceve's poetic rendering of her as his object of love. Rather, she expands her role into that of answering poet/lover. Whereas Labé rewrites her role as a woman in poetry, Pernette outwardly accepts her role as silent Petrarchan lady while creating a new role as a Neoplatonist poet who answers her lover in a poetry focused on the refined, purer aspects of love rather than writing with the passionate voice employed by the Petrarchan poet/lover.

One manifestation, however, of Pernette's foray into Petrarchism is found in spigram XIII. Her vocabulary here is traditionally Petrarchan with an interesting intertextual theme. The god "Amour" is the "Dieu aveugl6" who, according to Pernette, "nous a faict avoir/ Du bien le mal en effect honnorable" (11, 5-6). This recalls Louise Labe's Debat de 
Folie et $d$ 'Amour, the account of Amour's blinding at the hands of Polie. To readers familiar with Labe's Débat, Pernette's reference to "Dieu aveuglé" appears to be an invitation to comparison with the former's work. That the invitation appears in Petrarchan language, unusual for Pernette, seems to indicate her sensitivity to their differences. 


\section{A CLOSE READING OP RYMES}

\section{THEME AND VOCABULARY}

An examination of the feminine poetic voice as seen in the Rymes of Pernette du Guillet is incomplete if it does not explore the extent to which Pernette's poetry reveals the woman behind the poet. For my purpose, "female voice" constitutes the characteristics that differentiate women's writings from men's writings. An exploration of Pernette's poetic voice must occur within the context of her affiliation with her lyonnais contemporaries so that it becomes clear why her work merits further detailed study. When her work is considered within the context of L'Bcole Lyonnaise, Pernette distinguishes herself as an able poet who is worthy of the same consideration that is given to scève and Labé.

I don't believe that a writer can write with a neutral voice, as Gillian Jondorf maintains. The poetry is an extension of the writer, who in this case is clearly a woman. If it is my contention that women experience lifo differently from men, I must also believe that the observations inscribed in their poetry contribute a necessarily different perspective. A woman's style reflects this contrasting view and her poetic voice must also reflect this difference. If my analysis is true, the feminine voice flows from the poet and 
the poetry reveals the writer's poetic identity.

Pernette's work is full of grammatical indications of her gender that are clearly evidence of the "feminine" sex of the poet. The French language reveals the sex of the writer with adjective and verb endings. However, these "marks" comprise a very superficial idea of her feminine poetic voice. If a "neutral" voice means that Pernette does not always reveal her sex through her grammar, then some of her poems are indeed "neutral." Gisele Mathieu-Castellani writes that "bien souvent les seules marques distinctives [in Rymes] sont gramaticales" ("Parole d'echo" 63). On the contrary, grammatical indications of the sex of the writer do not demonstrate the extent of the feminine voice. These are all too obvious indications that the writer is a woman. Pernette's gex is frequently very evident in her poetry. In Epigram I she writes, "Dont congnoissant celuy qui m'est promis/ Resté suis sans sentyment de vie" (11. 3-4), which shows not only her sex but the sex of her lover as well. Bpigram XXIII describes pernette as "si indiscrette" and she is "la Journée" to sceve's "Jour" in Chanson IX.

Mathieu-Castellani dismisses Pernette's poetry as "chetif," indicating that the only noteworthy significance stems from her subtle imitation and "personal" subject matter. The opposite is closer to the truth. Pernette reveals her separate poetic identity through her manipulation of traditional genres. Purthermore, her transformation from 
Petrarchan object into a gifted Neoplatonist lover/poet shows that she accepts her feminine identity. Instead of appropriating the male Petrarchan persona, she writes as a woman who is both lover and poet. Within the confines of Neoplatonism, Pernette is able to exercise her identity as both a recipient of Sceve's love and poetry as well as being the author of her own poetry of love. While Louise labé radically challenged the dominant male patriarchy when she assumed the role of Petrarchan poet/lover, Pernette rebels quietly through her use of themes and vocabulary. She manipulates her vocabulary to reveal the woman behind the poetry and her feminine poetic voice.

Her work is a poetic correspondence with Maurice scève that seemingly reinforces her claim of submission to her lover at the same time that it showcases her adept ability as a poet. Mathieu-Castellani writes, "parole ch6tive, certes et aux deux sens du terme: faible et fragile, en effet, mal assuré et comme hésitante; mais captive aussi, prise dans le texte, dans la parole de l'autre; parole d'écho" ("Parole chétive" 48). On the contrary, Pernette's style and her complex manipulation of Sceve's themes as well as his characterization of her in DElie frequently contradicts her ostensiblely yielding vocabulary. While it is true that "les marques de soumission sont dispensées sans compter" ("Parole chetive" 49), it is also true that pernette often uses these indications of subservience to delineate the roles in her love 
relationship. When she calls sceve the "Jour" and designates herself as the "Journee" in Chanson IX, she makes it clear that "Jour" and "Journee" symbolically represent two lovers who are two parts of one whole. She skillfully renders the genders of herself and sceve as well as conveying the roles each lover plays in their relationship. Pernette's "Journée" is the qualitative, enduring aspect of Sceve's "Jour." It is clear that Pernette considers scève her master in Bpigram XLVIII: "A qui est né pour estre sur moy maistre," but "maistre" does not necessarily refer to his role as teacher. Pernette's poems that refer to sceve in this role have a twofold meaning. On the one hand, she is his student and he, obviously the teacher. On the other hand, Pernette suggests that sceve is the aggressor in love as well. On the surface, her poetry is less erotic and less focused on the physical aspect of love than is that of her mentor. Pernette infuses her poems with an apparent significance and leaves the secondary interpretation to the reader. For example, Bpigram XXXIV is addressed to sceve the master, but it is not Pernette the student poet who speaks; Pernette writes as the disappointed lover:

Puis que, de nom et de faict, trop severe Bn mon endroict te puis appercevoir, Ne $t$ 'esbahis 8 i point je persevere A faire tant, par art, ot par sçavoir, Que te lairras d'aller les autres veoir: Non que de toy je me voulsisse plaindre, Comme voulant ta liberté contraindre! Mais advis m'est que ton sainct entretien 
Ne peult si bien en ces autres empraindre

Tes motz dorez, comme au cueur, qui est tien.

Pernette never overtly criticizes Scève without qualifying her appraisal. After telling him that he has been too severe in his disapproval, she praises him and assures him that she is completely his, regardless of his criticism. This poem is well constructed and begins with a jeu de mots based on Scève's name and his action. Whereas Pernette seems to reinforce her role as a subservient student, she actually demonstrates her virtuosity and singular style. This poem is also interesting because Pernette addresses her lover with "tu" instead of "vous." This is another subtle means of declaring her equality as a person and as a poet, since Pernette frequently, but not always, employs "vous" in her poetic address.

Pernette's assumed Neoplatonist persona allows the poet/lover she has become to respond to sceve's dizains with a poetic voice that can be feminine without invalidating his description of her as the Petrarchan object of his poetry. She answers his invitation to love with her own call to a higher, purer understanding of the meaning and repercussions of love. She manages to praise sceve, enumerate her own short-comings as a poet, and to extol the virtues of "une parfaicte amytie" within the confines of well-constructed poems that leave no doubt as to the quality of her work. Purthermore, it is clear that she considers herself very capable of maintaining the delicate balance between her role as Petrarchan object and 
Meoplatonist writer.

Sceve personifies Pernette du Guillet as the "objet de plus haute vertu." He is the lover and she is the virtuous object of his affections and the inspiration of his poetry. When Pernette assumes the identity of poet, she places sceve in the role of object of love. She speaks directly to him in many of her poens: "Pour la vertu, dont es la source" (Epigram IV). Whereas Louise Labe relegated her lover to the role of Petrarchan object that she had vacated upon assuming the role of poet, Pernette places sceve in the role of inspiration and Neoplatonist exemplifier of "Vertu."

In her article "Ardeur de veoir': Reading Knowledge in Pernette du Guillet's Rymes," Jan Boney discusses the meaning of "vertu." She contends that Pernette refers to sceve's virtuosity and style when she uses the word "vertu." Although this is indeed one of the meanings of "vertu," Pernette deliberately plays with the various connotations of rords as well as the plurality of interpretation. As a Neoplatonist poet, she writes about love as a purer essence epitomized by the "vertu" of her mentor and supreme example of the embodiment and ideal for which she strives. The nature of Meoplatonism allows sceve to maintain his dignity as the foremost Pertrachan poet in Prance whereas Louise Labe's Petrarchism imbues her lover with many of the qualities of a typical Petrarchan object, at the same time that he keeps his "masculine" attributes. 
Pernette's poetry is full of contrasts that exemplify her feminine poetic persona and Neoplatonism. She explores the dichotomy between her lover's vision of love and her own perception, contrasting the physical with the spiritual in her analysis of desire. Whereas the masculine poetic notion of love is centered on the female body and passion, her own interpretation and feelings are rooted in spiritual bonding and the process of love, instead of the culmination of physical passion:

Le grand desir du plaisir admirable Se doit nourrir par un contentement De souhaicter chose tant agreable, Que tout esprit peult ravir doulcement. o que le faict doit estre grandement Remply de bien, quand pour la grand envie On veult mourrir, s'on ne l'a promptement: Mais ce mourrir engendre une autre vie. (Bpigram XIV)

This is a poem of contrasts between the erotic and the gentle. She juxtaposes Meoplatonist ideas with traditionally Petrarchan images and vocabulary where "plaisir" is "admirable" and "tout esprit peult ravir doucement." Love is "remply de bien" and passion is equated with death and another level of love; it leads to "une autre vie" that Pernette seems to fear.

Several of Pernette's poems are dedicated to these contrasts between body and spirit. She departs from her mentor's ideas of love and writes in a distinctive manner that further serves to demonstrate her particular feminine poetic 
voice and feminine vision. Her definition of love is very different from Scève's masculine preoccupation with the physical joy of love. In Bpigram XI Pernette describes the body as being separate from the spirit: "Comme le corps ne permect point de veoir/ A son esprit, ny sçavoir sa puissance" (11. 1-2), and yet the pleasure of love is increased when it is a joint pleasure. When the body and soul are in agreement: "Le corps ravy, l'Ame s'en esmerveille/ Du grand plaisir, qui me vient entamer..." (Bpigram XII 11. 1-2). The unity between the body's passion and the spirit's desire create the perfect setting in which love flourishes: "L'ame et l'esprit sont pour le corps orner/ Quand le vouloir de l'Bternel nous donne/ Sens, et sçavoir pour pouvoir discerner/ Le bien du bien, que la raison ordonne" (Bpigran XVI 11, 1-4).

Neoplatonism battles with Petrarchism within Pernette as well as within the confines of her poetry. She contrasts her Neoplatonism with the Petrarchism of her lover and mentor while frequently employing Petrarchan terms in her own work:

Bn lieu du bien que deux souloient pretendre, Je veulx le mal toute seule porter: Puis que malheur ainsi me veult surprendre, Il est besoing qu'apprenne supporter.

o foy, amour, plaisir, se contenter, Ce n'est moyen de mon mal subvertir. Helas, j'ai bien cause de regrecter Ce qui souloit en deux se despartir. (Epigram XLIV)

The Petrarchan vocabulary is evident in this poem. Instead of trying to distinguish her poetic voice from that of her lover, 
Pernette allows herself to sink into depressed contemplation, relying on the Petrarchan theme of "regret" to voice her absence of hope: "Ce n'est moyen de mon mal subvertir." "Le mal" has replaced "le bien" and although she addresses the Neoplatonist concept of "contentement" in love, she sees no hope of escaping her unhappiness.

Elegy I offers a sharp contrast to the despondency of Epigram XLIV. She reverts back to a more positive concept of her perfected love. If love is sometimes a battle of wills and desires between two lovers, Pernette realizes that she is nonetheless blessed with a "parfaicte amyti6":

Quand est d'Amour, je croy que c'est un songe, ou fiction, qui se paist de mensonge, Tant que celuy, qui peult plus faire encroire sa grand faintise, en acquiert plus de gloire. Car l'un faindra de desirer la grace,

De qui soubdain vouldra changer la place:

L'autre fera mainte plaincte a sa guise,

Portant tousjours 1 'amour en sa devise,

Bstimant moins toute perfection

Que le plaisir de folle affection:

Aussi jamais ne s'en trouve un content,

Fuyant ie bien, ou tout bon cueur pretent.

Bt tout cela vient de la nourriture

Du bas sçavoir, que tient la creature. Mais l'amyti6, que les Dieux m'ont donnée,

Bst l'honneur toute tant adonné

Que le moins seur de mon affection

Est asseur6 de toute infection

De Paulx semblant, Danger, et Changement,

Bstant fondé sur si sain jugement Que, qui verra mon amy apparoistre, Jamais fasché ne le pourra congnoistre: Pource qu'il est tousjours a son plaisir Autant content que contient mon desir. Bt 8 i vous voulez sçavoir, 8 Amoureux, Comment il est en ses amours heureux: C'est que de moy tant bien il se contente, Qu'il n'en vouldroit esperer autre attente. 
Que celle la qui ne finit jamais.

Bt que j'espere asseurer desormais

Par la vertu en moy tant esprouvée.

Qu'il la dira es plus haultz Cieux trouvée.

Parquoy, luy seur de ma ferme asseurance,

M'asseureray de craincte, et ignorance.

This well-crafted poem is comprised of contrasts both in theme and at a structural level. The first half is dedicated to the description of the carnal love that exists on a physical plane in the world. The second half describes her own experience of a love that is founded on mutual respect and "le bien." Her needs are met when her lover is "content." This idea is present in several of her poems. Her happiness stems from his. The ideal love described in this poem offers a more erotic view of love than that which Pernette usually describes: "Pource qu'il est tousjours son plaisir/ Autant content que contient mon desir." However, she contrasts her perfect love with a more worldly experience in lines 9-13: "Bstimant moins toute perfection/ Que le plaisir de folle affection... / Fuyant le bien.../ Bt tout cela vient de la nourriture/ Du bas sçavoir, que tient la creature." Her physical satisfaction in love in no way resembles that experienced by others because the core of her love is spiritual. If the love relationship described in Rymes is physical as well as psychological, it is purer because it is based on intellectual affinity, not erotic desire. The poet of Rymes underlines this motif often, assuming a distinct poetic identity in her work. The woman is never far from her poetry. 
The contrasts between Pernette's Neoplatonism and Scève's Petrarchism are numerous. Pernette also draws attention to the differences between herself and her mentor at the level of poetic construction. Her poems of fer two-sided contrasts. That is not to say that her work is two-dimensional. On the contrary, her poems present love as a reality experienced by two well-delineated individuals, based on herself and her lover/teacher. They experience all of the joys, sorrows, and jealousies of love. Her contrasts, however, offer two extremes in the portrayal of love. Black becomes white in Bpigram V: "Puis que desir de me transmuer as/ De noire en blanche, et par si hault service..." (11, 8-9). Pernette describes two states of being, "ignorance" and "sçavoir," without leaving any possibility for anything between the two in Bpigram XXIII:

Je puis avoir failly par ignorance, Cela me fault, maulgré moy, confesser:

Mais que je prenne en moy telle arrogance, Que dessus vous je m'osasse avancer: Je vous supply ne me vouloir penser $\mathrm{Si}$ indiscrette a faire mon debvoir. Bien est il vray que je tasche avoir Ce qui m'est deu, quoy qui en ait esmoy: Car si Amour, et foy ont ce pouvoir De vous donner, vous estes tout a moy.

Her inability to measure up to her idealized representation of her mentor is always attributed to her "ignorance." This poem is particularly interesting because it reveals that Pernette was accused, perhaps by Scève himself, of trying to usurp his position. While she apologizes for her "arrogance," she does 
not say that she is incapable of achieving equal success. The last four lines are clearly an excuse for her behavior that hints that her poetry may be worthy of consideration on level with his: "Bien qu'il est vray que je tasche à avoir/ Ce qui m'est deu." The last two lines seem almost too submissive. Pernette voices two concerns in her poetry: she wants to attain the level of "vertu" in her work that her mentor has achieved in his, and she wants sceve to love her and belong only to her as she belongs to him. These two desires appear to be honest sentiment on Pernette's part. However, there is more here than what she says. These two thoughts also serve to protect her from a certain amount of criticism. Her elaborate praise and obvious love for her mentor act as a "disclaimer" for any secondary interpretations of her work. She creates her own poetic persona through her plural meanings that does not jeopardize her standing as a woman who is also a poet.

It is clear that Pernette's work springs out of events from her life. To a certain extent her work can be called autobiographic in nature. As I have already observed, the love portrayed in Rymes stems from a real relationship between herself and Maurice sceve. She gives an honest account of the joy involved in love as well as the jealousy and fear. Pernette's most obvious contrast and her clearest indication of the real relationship behind the poetic one is her use of the word "Jour" to represent Sceve and as a contrast to "la nuict." In Chanson IV, he is the "Jour" that brings her joy: 
"Voyant mon Jour passer/ De la nuict est joyeuse" (11. 2-3). Pernette praises Sceve for his "vertu," his "loz," and his "grace." Once again she ends the poem with a disclaimer: "Bt si je n'ay la grace/ Pour meriter d'avoir/ Ce bien, et qu'on pourchasse/ De le me decevoir/ Ma fermeté fera/ Qu'il se contentera" (11, 55-60). She qualifies some of her most striking work so as not to appear too forward. She lets the obvious quality and maturity evident in her poetry speak for her.

several of Pernette's poems repeat this contrast of "Jour" and "Nuict." Bpigram II is the first to characterize Sceve as the "Jour au Monde". Epigram VIII continues this idea as well as subtly introducing the added dimension of the "Nuict" as the scene of Pernette's fear. Some scholars suggest that this comparison between "Jour" and "Nuict" is also between sceve and her husband. I think that there is no doubt about this. Her association of sex and night and her distaste and disdain for the purely physical side of a relationship make this very clear. sceve illuminates her spirit and gives her inspiration:

Ja n'est besoing que plus je me soucie si le jour fault, ou que vienne la nuict, Nuict hyvernale, et sans Lune obscurcie:

Car tout cela certes riens ne me nuit, Puis que mon Jour par clarte adoulcie M'esclaire toute, et tant, qu'a la mynuict

Bn mon esprit we faict appercevoir

Ce que mes reulx ne sceurrent oncques veoir. (Bpigram VIII) 
Pernette devotes several poens to the differences between her husband and Scève. "La Nuict" is the incarnation of her husband and his place in her life in the same manner that the "Jour" represents Scève. Graham asserts, with reason, that Epigram XXXV contrasts Pernette's feelings for her husband and Scève:

Si j'ayme cil, que je debvrois hayr, Bt hays celuy, que je debvrois aymer, $L$ 'on ne s'en doit autrement esbayr, Bt ne m'en deust aucun en rien blasmer. Car de celuy le bien dois estimer, Et si me fuict, comme sa non semblable: Mais de cestuy le plaisir trop damnable M'oste le droict par la Loy maintenu. Voila pourquoy je me sens redevable, A celuy la, qui m'est le moins tenu.

The comparison is all too evident: she loves the one she should hate (Sceve) and hates the one she should love (her husband). In Chanson IX she plainly declares that "d'aymer la Nuict certes je ne veulx point" ( 1 ine 5) and "ce que la nuict cache/ Paisant mille maulx/ Bt ne veult qu'on sache/ Ses tours fins, et caultz" (11, 27-30). When Pernette describes the night, it is always "obscure," "triste," and "sombre" (Blegy III), whereas it is the "Jour," Pernette asserts "qui n'a destournée/ De fascheux sejour" (Chanson IX 11. 3-4). In other words, it is the presence of sceve in her life that rescues her from the distasteful night and the unwelcome presence of her husband.

Bpigrams XXXVIII through XL elaborate Pernette's 
conception of sceve as her inspiration, illumination and veritable savior from "la Nuict." In Bpigram XXXVIII she writes that her "Jour" is "bien à moy: car il m'a prevenu/ Tesmoing n'en veulx que la perseverance/ Par qui il est tant alle, et venu/ où moins doubtois en ma foible asseurance." Pernette's "Jour" is omnipotent in Bpigram XXXIX:

Comme mon Jour, il peult partout aller, Par une mode au soleil coustumiere: Lequel l'on voit monter, et devaller, Tournant reveoir sa region premiere. Car de ses rayz toutes faict lumiere, Veu qu'elles ont d'ignorance la nuict: Mais il y est comme au feu la fumiere: Plus elle est noire, et plus fort il reluict.

Line eight demonstrates the breadth of Pernette's education with the intertextual Biblical allusion. It is in sin that God is able to perform the miracle of salvation and for Pernette, her "savior" from the blackest night is the one who illuminates her days and rescues her from the night.

Bpigram XL continues the description of Pernette's "Jour" and begins another theme that Pernette manipulates to show her feminine interpretation and depiction of jealousy. In this poem, her "Jour" is "assis tout aupres d'une," that is, another woman. Pernette does not express Petrarchan desperation when faced with a rival in love. Although she dislikes the presence of the "other woman," she is disdainful, and as Gillian Jondorf has observed, certain of her own superiority (769). 
Pernette's adept treatment of the theme of jealousy is one of the ways in which she distinguishes herself from her Petrarchan lover/mentor. In addition, her mature expression establishes her as a distinct feminine poetic presence. Instead of writing from the standpoint of wrathful "wronged woman" or desperate lover, she is straightforward and logical. She presents the disappointment of a mature woman who considers herself worthy of love. In Epigrams XXXI and XXXII Pernette voices her displeasure at her lover's inconstancy:

Je ne croy point ce que vous deites:

Que tant de bien me desirez,

Comme à celle, pour qui vous feites

Ce que pour vous faire debvriez.

Mais quelle plus estimeriez:

ou celle qui, d'un cueur tremblant, N'ose dire ce que vouldriez,

ou qui le dict d'un faulx semblant? (XXXI)

L'une vous ayme, et si ne peult sçavoir

Qu'Amour luy soit ou propice, ou contraire:

L'autre envers vous faict si bien son debvoir,

Que plus ne sçait, ou vous doibve complaire.

Or je demande en si doubteux affaire

A quelle plus debvez estre tenu?

Car celle là d'un cueur simplement nu

Pour vous se ouble, et pour soy pensive est:

Et ceste CY, taschant par le menu

$A$ vous gaigner, de son bien se devest. (XXXII)

Pernette is unsure of her lover's feelings. She compares herself to her rival, describing herself as the constant, sincere woman with "un cueur tremblant" and "simplement nu" who cannot express how she feels, and her rival as the woman 
who is trying to supplant her, saying all of the right things but "d'un faulx semblant." The false lover lacks the real love behind her actions. Pernette's love, however, is genuine, although she is too timid to give voice to it. Her stance as the shy subservient lover is probably overstated to maximize the effect of her poem. She presents herself in such a way as to allow her comparison between the two rival woman to present the extremes. She never says that she is jealous, only that two women vie for Sceve's love and she, Pernette, is the worthier by far.

Her stance in Bpigram XXXVI is 1 ess theoretical and closer to revealing a situation borrowed from her reality. She writes that her problem is jealousy and that it was brought about by something that she saw with her own eyes and according to her poem, misinterpreted:

Si descharger je veulx ma fantasie Du mal que $j$ 'ay, et qui me presse fort, On me dira que c'est la jalousie (Je le scay bien) qui faict sur moy effort. Mais qui pourroit estre en propos si fort, Bt d'argumentz si vivement pourvueu, Que ce que $j$ 'ay de mes propres yeulx veu Soit une folle imagination Il feit accroire à mon sens despourveue? Il we feroit grand' consolation!

The woman behind this poem seems less haughty and sure of herself than in the two preceding ones. Whereas she presented a facade of a timid, but worthy woman who was obviously more steadfast than her rival in Bpigrams XXXI and XXXII, Pernette 
seems almost apologetic in this poem. She places herself in the wrong, accepting the responsibility for whatever she inadvertently misinterpreted. Underneath her acceptance and words of faith she seems unsure of herself and her lover. These three poems dealing with jealousy fit very nicely together as a succinct representation of Pernette's feminine voice. Pernette uses several themes and layers of meaning to demonstrate her personal world view. She balances seemingly contradictory rebellion with praise and reticence. The quality of her poetry and the maturity of her poetic voice often convey a completely different impression from the simple words that she uses.

The French writer Hélène Cixous maintains that we write what we are. Pernette du Guillet was a sixteenth-century woman who wrote poetry that was, in her own words, indivisible from her body and her spirit. Pernette equates the unveiling of her feelings in her work with the nudity of her body: "Veu que par ton moyen Vertu chassa la nue/ Qui me garda long temps de me coignoistre nue/ Bt frustrée de bien" (Chanson vI lines 2729). Her body is linked to her words. Her enlightenment is two-fold: her "Jour" is "comme au feu la fumiere" (Bpigram XXXIX line 7 ). He inspires the poet in her as well as introduces her to the wonder of a love that is both spiritual and fulfilling. Pernette is, in effect, her poetry. Her work is revealed to the male gaze and she is laid bare to the appraisal of her lover, much as he would examine her naked 
body. She is unable to conceal anything in the nakedness of her work.

Pernette the woman is omnipresent in Rymes. This presence is both gentle and controlled. Her work is intimate, personal, and in many ways, indivisible from her self. Although I do not agree with Gisele Mathieu-Castellani's global evaluation of Pernette's work, her suggestion that "la liquidite" of Pernette's writing is one of the things that distinguish her work from the "dure ecriture" of scève is true. Pernette's poetic voice is an extension of her very being; it is never far from her heart and feelings. This poetic voice is what Mathieu-Castellani calls "simplicité... cette présence de la voix dans un texte qui s'oralise, ce 'corporage' qui restitue son langage au corps, on les tiendrait volontiers pour des marques du fominin..." ("Parole d'6cho" 69). The word "marques" is a good choice because there is no one thing that "equals" the feminine poetic voice in a text. Pernette's voice is a combination of many factors that merge to create a unique poetic presence that is decisively her own.

Perhaps one of the most significant indications of Pernette's feminine voice is the restraint that her Heoplatonist poems reveal. This desire to hide her feelings behind "safe" vocabulary could be the product of a woman's limited role in Renaissance French society as well as in the world of Letters. Pernette outwardly preserves the status guo In her work. Although she does not question the dominant 
patriarchy, her poetry subverts the male dominance that she claims to revere. Her reputation does not suffer and her work is viewed as an extension and complement to that of Maurice Sceve. This restraint leads to the only real power that she was able to wield; her seeming acceptance of her role allows her to introduce her ideas about love and a woman's place in this relationship.

What some scholars label "neutral" because it lacks obvious feminine grammatical indications is really rather revelatory of her mature attitude about love. Epigram XXI is remarkable for both its restraint in the face of passion and for its beauty: "Si le servir merite recompense/ Bt recompense est la fin du desir/ Tousjours vouldrois servir plus qu'on pense/ Pour non venir au bout de mon plaisir." Her choice of vocabulary is Petrarchan, but the theme is definitely Meoplatonist. She values the daily interaction involved in love. She does not seek the culmination and she chides, indirectly, her lover's erotic preoccupation. Based solely on this poem, it is not clear that the writer is a woman. However, familiarity with the work of Pernette and the themes she favors leave no doubt that Rymes is the work of a thoughtful, creative poet whose feminine poetic voice is the source of many well-conceived poems.

POBTIC MBRIT

Unlike DGlie, which was composed entirely of dizains, 
Pernette incorporates poems of differing lengths in her work. She too uses dizains, as well as huitains, quatrains, Blegies, and Chansons. Judged purely from a structural point of view, her poems are very well-crafted. Her rhyme is perfect and the final words of each line often intentionally reflect the mood and theme of the whole poem. Bpigram XXI, for example, describes Pernette's feelings about the purpose of love and the final words of each line are "recompense," "desir," "ne pense," and "plaisir." She gives important information in her vocabulary choice without sacrificing the structural integrity of the poetry. Pernette varies the format of her work, sometimes addressing her poems to her lover, and at other times to her audience about her lover. The "poetics of group identity" as defined by Ann Jones adds another nuance to the possible shades of meaning evident in Pernette's work; her poetry is meant to be read and interpreted in conjunction with that of her contemporaries. She creates and re-works similar themes.

Pernette's work is solid and purposely well-constructed. Some of her poems are particularly sensitive for their union of beauty and theme. Bpigrams XXIV and XXV form a unit on the thematic level and both demonstrate Pernette's proficiency as a capable poet who cannot be judged a weak imitation of either Maurice Scève or Louise Labe.

A qui est plus un Amant oblige Ou a Amour, ou vrayement a sa Dame? 
Car son service est par eulx redigé

Au ranc de ceulx qui ayment los, et fame.

A luy il doibt le cueur, à elle l'Ame:

Qui est autant comme a tous deux la vie:

L'un a l'honneur, l'autre a bien le convie:

Bt toutesfois voicy un tresgrand poinct,

Lequel me rend ma pensée assouvie:

C'est que sans Dame Amour ne seroit point. (XXIV)

Or qui en $a$, ou en veulx avoir deux,

Comment peult il faire deux Amours naistre?

Je ne dy pas, que ne puisse bien estre

Un cueur plus grand, que croire je ne veulx:

Mais que tout seul il satisfeit à eulx,

Cela n'a point de resolution,

Qui sceust absouldre, ou clorre ma demande:

Bt toutesfois ainsi qu'affection

Croist le desir, telle obligation

Peult Dame avoir à la Vertu si grande,

Que de l'Amant la qualité demande

Double merite, ou double passion. (XXV)

Bpigram XXIV illustrates the separation between the ideal and the reality of love. It begins as a serious discussion that mirrors the Renaissance debate between the superiority of "les mots" and "les choses." Her answer is a playful reminder that without one, the other ceases to be relevant. Epigram XXV continues the same theme without revealing the identity of the "deux Amours." While it is possible that she is referring to two different lovers, the previous poem seems to indicate that the "deux Amours" are love and his lady. Pernette addresses mature issues in her work that a less capable poet would be unable to manage. She does not merely parrot the same themes that she finds in the poetry of the day. She deals with love on several levels instead of using her poems as a forum for 
complaining about the difficulty in being a woman poet cast in the shadow of a well-known lover/poet.

Many of Pernette's poems seem to have been written especially for oral recital. Indeed, several were set to music during her lifetime. Pernette's use of vowels makes Chanson II particularly beautiful when recited aloud:

o vraye amour, dont je suis prise,
Comment m'as tu si bien apprise,
Que de mon Jour tant me contente,
Que je n'en espere autre attente,
Que celle de ce doulx amer,
Pour me guerir du mal d'aymer?
Du bien j'ay eu la jouyssance,
Dont il m'a donne congnoissance
Pour m'asseurer de l'amytie,
De laquelle il tient la moytie:
Doncques est il plus doulx, quamer,
Pour me guerir du mal d'aymer.
Je ne puis avoir asseurance
Que celle dont (pour son plaisir)
Amour cault me vient dessaisir
Pour me surprendre, et desarmer:
Gueris moy donc du mal d'aymer!

Pernette addresses the subject of her perfect love and the joy that it brings her. She uses Petrarchan vocabulary to contrast with her Neoplatonist viewpoint. The repetition of "pour me guerir de mal d'aymer" and finally "gueris moy donc du mal aymer" serve as reminders that although her love pleases her, there is the negative aspect of "doulx amer" that agitates her. Part of the beauty in this poem is the sound of the words that she chooses as final words to complete the rhyme. The feminine endings "prise," "apprise," "contente," "attente," 
"jouyssance," "congoissance," "amytie," "moytié," "absence," and "asseurance" achieve a particularly pleasant effect together. The other final sounds are "er," with the two exceptions of "plaisir" and "dessaisir". The change in the final sounds calls attention to these words. Once again, these final words give a clue to the developing theme in the poem. Chansons VIII and IX are, in my opinion, Pernette's two best pieces. Both are superb testaments to the breadth of Pernette's talent:

Heureuse est la peine

De qui le plaisir

A sur foy certaine

Assis son desir.

L'on peult assés en servant requerir,

Sans toutesfois par souffrir acquerir

Ce que l'on pourchasse

Par trop desirer,

Dont en male grace

Se fault retirer.

car un tel service

Ne pretend qu'au poinct,

Qui par commun vice

L'honneur picque, et poinct.

Bt ce travail en fumbe devient

Toutes les fois, que la raison survient,

Qui tousjours domine

Ton cueur noble, et hault,

Bt peu a pou mine

Le plaisir, qui fault.

Mais I'attente mienne

Bst le desir sien

D'estre toute sienne,

Comme il sera mien.

Car quand Amour a Vertu est uny,

Le cueur conçoit un desir infiny,

Qui tousjours desire

Tout bien hault et sainct,

Qui de doulx martire

L'environne, et ceinct.

Car il luy engendre

Une ardeur de veoir, 
Bt tousjours apprendre

Quelque hault sçavoir:

Le sçavoir est ministre de vertu,

Par qui Amour vicieux est batu,

Et qui le corrige,

Quand dessus le cueur

Par trop il se erige

Pour estre vainqueur.

C'est pourquoy travaille

Bn moy cest espoir,

Qui desir me baille

Bt veoir, et sçavoir.

Estant ainsi mon espoir asseuré,

Je ne crainct poinct, qu'il soit demesuré:

Mais veulx bien qu'il croisse

De plus en plus fort.

A $f$ in qu'apparoisse

Mon cueur ferme, et fort.

Et que tous jours voye

Travaillant ainsi,

Tenir droict la voye

D'immortel soucy.

si donc il veult en si hault lieu monter

Qu'il puisse Amour, et la Mort surmonter,

sa caducque vie

Devra soulager

D'une chaste envie

Pour 1 'accourager.

Ainsi m'accompaigne

Un si hault desir

Que pour luy n'espargne

MoY, ne mon plasir. (VIII)

This is Pernette's poetic voice at its peak. She makes no attempt to hide her gift behind false modesty or words of praise for the work of another. She transfers her very essence onto the page, laying herself bare to criticism and judgement. Chanson VIII confirms that she is firmly in command of her subject matter and that she is the master of her expression.

While Chanson VIII begins like a traditional Petrarchan poem, juxtaposing love's happiness with pain, the poem in its entirety is firmly rooted in Pernette's Neoplatonism. She 
blends her praise for her lover: "Ton cueur noble, et hault," with an analysis of the nature of a perfect love relationship in the first four lines. Pernette treats a common theme from a new point of view, comparing the impatience of her lover to her own patience and restraint.

Lines 21-24 display her playfulness and wit when compared with the more serious demeanor scève presents in his work. Her jeux de mots with "mienne," "sien," "sienne," and "mien" indicates Pernette's awareness of her role as a woman poet with her own perception of a feminine poetic voice. "L'attente" designates her role as a sixteenth-century woman in society as well as in the realm of literature. Men are traditionally the aggressors in love while women wait to be summoned. Pernette chooses feminine words, "l'attente mienne," to represent her position as a woman in society and in love. Her analysis of love usually includes a comparison between "le desir" of her lover and her own restraint in the face of passion. "Le desir" in line 22 reflects the passionate prerogative of men and it is rendered by the masculine "sien." In lines 23 and 24 she uses her choice of language to strengthen the correlation between the people behind the poetic personae. Pernette is his and "sienne" reflects her sex. Her lover will be hers and "mien" is masculine in order to represent the man behind the relationship.

Pernette's Neoplatonist ideology constitutes the road to ultimate fulfillment when "Amour vertu est uny" (1ine 25) 
and "envie" is "chaste" (line 59). Pernette develops her theme and finds her own voice, separate from the voice of her lover, in which she combines admirable poetic form and mature content. Her best work demonstrates that she is able to blend her themes into structurally beautiful poems without sacrificing her identity as a woman poet.

Chanson IX is another example of the union of a wellconstructed poem and personal sentiment:

Je suis la Journée,

Vous, Amy, le Jour,

Qui m'a destournée

De fascheux sejour.

D'aymer la Nuict certes je ne veulx point,

Pource qu'a vice elle vient toute appoint:

Mais a vous toute estre

Certes je veulx bien,

Pource qu'en vostre estre

Ne gist que tout bien.

Là où en tenebres

on ne peult rien veoir

Que choses funebres,

Qui font peur avoir,

On ne peult de nuict encor se resjouyr

De leurs amours faisant amantz jouyr:

Mais la jouyssance

De folle pitie

N'a point de puissance

Sur nostre amytié,

veu qu'elle est fondée

Bn prosperité

sur vertu sondée

De toute equité.

La nuict ne peult un meutre declarer,

Comme le jour, qui vient à esclairer

Ce que la nuict cacho,

Faisant mille maulx,

Bt ne veulx qu'on sache

Ses tours fins, et caultz.

La nuict la paresse

Nourrit, qui tant nuit:

Et le jour nous dresse

Au travail, qui duit. 
o heureux jour, bien et doit estimer

Celle qu'ainsi as voulu allumer,

Prenant tousjours cure

Reduire a clarte

Ceulx que nuict obscure

Avoit escarté!

Ainsi esclairée

De si heureux jour,

Seray asseuree

De plaisant sejour.

Pernette mixes all of her preferred themes: respect and love for her mentor, the contrast between "Jour" and "Kuict," her fear and dislike for the "Nuict," her Neoplatonism, and the inspiration she finds in her love. Her choice of "Journée" for herself and "Jour" for Sceve does not appear to indicate a subservient attitude. With her deliberate choice of the feminine form of "Jour," Pernette draws attention to her sex. She did not choose to call herself the "Lune" to sceve's "Jour" and "Soleil." Instead, she chose the feminine counterpart of her lover's "Jour" showing that she revels in her feminine identity both as the lover described in Delie and as the woman poet of her own work. 


\section{CONCLUSION}

Does the label "woman writer" impose certain characteristics dependent solely on gender? Theoretically, no. In practice, however, societal definitions of gender do, to a certain extent, shape the boundaries of women's roles. If a woman's writing is an extension of her being, her literary voice is, by definition, feminine-that is, of woman. However, there is no easily definable quality that is "the feminine voice" as expressed by all women in literature. Bach writer expresses his or her own voice in a way that is particular to that writer.

Pernette's poetic voice is comprised of many different elements. She establishes her poetic identity by situating herself within the context of her lover/mentor's writing and finally within the larger context of her community. Her Neoplatonism vis-a-vis the Petrarchism of Maurice Sceve is the first clue that her poetry will embody characteristics different from those of her mentor. She rejects his narrow characterization of her as his Delie and molds a new role for herself. Her poetic persona gives her the freedom to express her own singular voice. In effect, she is her poetry. This concept of a woman as her writing is not new. Women have always been identified with their work and judged inseparable from it. The difference in Pernette's case is that this 
"judgement" is not negative; she writes that her Rymes reveal her inner self. Her expression is intimate and personal.

Pernette is the product of her environment and time. She is a sixteenth-century poet who viewed herself as a woman first and a poet secondly. Her love relationship with Maurice Sceve is the single most important element in her transformation into a capable poet. His inspiration and tutelage provide the raw ingredients that allow her to blossom into a poet, but it is her courage to experiment that help her to grow into an able poet capable of truly creative work.

To my mind, many scholars stop short of a full appreciation of the refinement and dynamic quality of her work. Although sue Spaull and Elaine Millard are not referring to Pernette when they write that "...by refusing to write what she is expected to write, woman can make her statement" (131), this assertion can certainly be applied to Pernette's poetry. Rymes merit further examination than scholars have to date offered.

Gisele Mathieu-Castellani states, "...la poésie de Pernette du Guillet paraft d'abord se réfugier a l'ombre de Délie et n'apporter à la parole magistrale qu'un écho assourdi, un "responsif" d'élève douée, mais encore immature" ("Parole chétive" 47). Yet Pernette's so-called "immaturity" is only a superficial interpretation of her work. Her poetic voice emerges out of her growth from student poet into mature adult poet. Her seemingly imitative style is her first step towards a unique voice. She is content to be a poet who is 
always aware of her "role" as a woman in a society that frowns on women's creative efforts. She accepts her boundaries and works within culturally imposed confines to write poetry that exhibits one aspect of her role-that of capable poet-without jeopardizing another part of herself-that is, her role as a student and a lover. Nevertheless, it is a mistake to assume that her successful juggling of roles is a product of latent "feminism" on her part. Critics may look for ideas to support their own definition of twentieth-century feminism, but although medieval and Renaissance women's literature often chronicles women's battle for self-expression in a masculine world, their intent does not necessarily coincide with our modern idea of feminism.

Feminine consciousness and the growing importance of feminist criticism are products of the search for a more balanced representation of women in literature. However, any attempt to enlarge the literary canon to include fuller participation on the part of women should not be synonymous with an attempt to narrow our examination to just women, focusing solely on the sex of the writer to the exclusion of literary merit. It should also not be an attempt to move towards some form of "androgynous" literary voice. Rather, the value of differing viewpoints is that they offer a more realistic portrayal of life. It is easy to fall into the trap of discounting the importance of differing viewpoints when we as critics focus too vigilantly on the sex of women writers. 
When feminist critics examine a woman's work, they are looking for indications of the writer's "feminine" nature- what distinguishes her work from that of a man. In one respect, this is what I have looked for in the writing of Pernette. Problems arise, however, when we focus too narrowly on the differences, further segregating women from full participation in literature. Women's writing should be judged first and foremost on its literary merit and value, not just viewed as an example of feminine writing. My purpose has been to use feminist criticism and my modern viewpoint to re-read Pernette's work from a new point of view, underscoring the value of her writing so that she can take her rightful place, a more prominent position that her work merits, in the traditionally male-dominated field of literature. 


\section{WORKS CONSULTED}

Anderson, Margret. "Peminism As A Criterion of the Literary Critic." Feminist Criticism: Essays on Theory, Pootry and Prose. Bds. Cheryl L. Brown and Raren Olsen. Metuchen, N.J., and London: The Scarecrow Press Inc., 1978. 1-10.

Ardouin, Paul. Maurice Sceve, Pernette du Guillet, Louise Labe: L'Amour a Lyon au temps de la Renaissance. Paris: Librairie A.-G. Nizet, 1981.

Bainton, Roland H. "Learned Women in the Sixteenth Century." Beyond Their Sex: Learned Women of the Buropean Past. New York: New York UP, 1984. 117-128.

Baird, Joseph L. and John R. Kane. La Querelle de la rose: Letters and Documents. Chapel Hill: University of North Carolina Press, 1978.

Beer, Gillian. "Representing Women: Re-presenting Women." The Feminist Reader: Bssays in Gender and the Politics of Literary Criticism. Bds. Catherine Belsey and Jane Moore. New York: Basil Blackwell, 1989. 63-80.

Boney, Jan. " 'Ardeur de veoir': Reading Rnowledge in Pernette du Guillet's Rymes." L'Esprit Créateur 30 (1990): 49-60.

Christine de Pisan. The Book of the City of Ladies. Bd. and Trans. Barl Jeffery Richards. New York: Persea Books, 1982 .

"Rondeau." Poesie lyrique au Moyen Age. Bd. Guillaume Picot. Paris: Classiques Larousse, 1988. 106.

Cixous, Hélène. "The Laugh of the Medusa." New French Feminisms. Bds. Blaine Marks and Isabelle de Courtivron. New York: Schocken Books, 1981. 245-264.

Cropper, Blizabeth. "The Beauty of Women: Problems in the Rhetoric of Renaissance Portraiture." Rewriting the Renaissance. Bd8. Margaret $W$. Perguson, et al. Chicago: The University of Chicago Press, 1986. 175-190.

Davies, Stevie. The Idea of Woman in Renaissance Literature: The Peminist Reclaimed. Brighton: Harvester, 1986. 
DeJean, Joan, ed. The Politics of Tradition: Placing Women in French Literature. Special Edition of Yale French Studies. Vol. 75 (1988).

Dellaneva, Joann. "Pernette du Guillet's Poetic Voice." Women in French Literature. Bd. Michel Guggenheim. New York: The Modern Language Association of America, 1977. 47-55.

Bllmann, Mary. Thinking About Women. New York: Harcourt Brace Jovanovich, 1968.

Ferguson, Margaret W. "A Room Not Their Own: Renaissance Women as Readers and Writers." The Comparative Perspective on Literature: Approaches to Theory and Practice. Eds. C. Koelb and S. Noakes. Ithaca: Cornell UP, 1988. 93-116.

Maureen Quilligan, and Nancy Vickers, eds. Rewriting the Renaissance: the Discourse of Sexual Difference in Barly Modern Europe. Chicago and London: The University of Chicago Pres8, 1986.

Ferrante, Joan M. "The Bducation of Women in the Middle Ages in Theory, Fact, and Pantasy." Beyond Their Sex: Learned Women of the European Past. Bd. Patricia Labalme. New York: New York UP, 1984. 9-24.

Feugere, Lên. Les Femmes poètes au XVIeme siecle. Paris: Didier et C. $-\theta, 1860$.

Gardiner, Judith Regan. "On Female Identity and Writing by Women." Writing and Sexual Diference. Bd. Blizabeth Abel. Chicago: University of Chicago Press, 1982. 177-191.

Gauthier, Xavière. "Is there Such a Thing As Women's Writing?" New French Feminisms. Bds. Blaine Marks and Isabelle de Courtivron. New York: Schocken Books, 1981. 161-164.

Goldsmith, Elizabeth D., ed. Writing the Female Voice: Essays on Bpistolary Literature. Boston: Northeastern UP, 1989.

"Authority, Authenticity, and the Publication of Letters by Women." Writing the Female Voice: Bssays on Epistolary Literature. Bd. Blizabeth Goldsmith. Boston: Northeastern UP, 1989. 46-59.

Graham, Victor E., ed. Rymes. Genève: Librairie Droz, 1968.

Jacobus, Mary. "The Difference of View." The Feminist Reader: Bssays in Gender and the Politics of Literary Criticism. Bds. Catherine Belsey and Jane Moore. New York: Basil Blackwell, 1989. 49-62. 
Jondorf, Gillian. "Petrarchan Variations in Pernette du Guillet and Louise Labe." Modern Language Review LXXI:4 (1976): 766-778.

Jones, Ann Rosalind. "Assimilation with a Difference: Renaissance Women Poets and Literary Influence." Yale French Studies 62 (1981): 135-153.

"City Women and Their Audiences." Rewriting the Renaissance: The Discourses of Sexual Difference in Barly Modern Europe. Chicago and London: The University of Chicago Press, 1986. 299-316.

- "Pernette du Guillet: The Lyonnais Neoplatonist." Women Writers of the Renaissance and the Reformation. Bd. Katherina M. Wilson. Athens and London: The University of Georgia Pres8, 1987. 219-231.

"Surprising Pame: Renaissance Gender Ideologies and Women's Lyric." The Poetics of Gender. Bd. Mancy $K$. Miller. New York: Columbia University Press, 1986. 74-95.

"Nets and Bridles: Barly Modern Conduct Books and sixteenth Century Women's Lyric." The Ideology of Conduct: Essays on Literature and the History of Sexuality. Bds. Nancy Armstrong and Leonard Tennenhouse. New York: Methuen, 1987. 39-72.

- The Currency of Eros: Women's Love Lyric in Europe 15401620. Bloomington, IN: Indiana UP, 1990.

Jordan, Constance. Renaissance Feminism: Literary Texts and Political Models. Ithaca and London: Cornell University Press, 1990.

Joukovsky, Prançoise. La Gloire dans la poesie française et néolatine du XVİ̀me siècle. Geneve: Droz, 1969.

Kelly, Joan. "Did Women Have a Renaissance?" Women, History and Theory. Chicago: Chicago UP, 1984.

Kelso, Ruth. Doctrine for the Lady of the Renaissance. Urbana: University of Illinois Press, 1956.

Kolodny, Annette. "Some Notes on Defining A 'Peminist Literary Criticism." "Feminist Criticism: Bssays on Theory, Poetry and Prose. Eds. Cheryl L. Brown and Raren olsen. Metuchen, M.J. and London: The Scarecrow Press Inc., 1978. 37-58.

Labalme, Patricia, ed. Beyond Their Sex: Learned Women of the Buropean Past. New York: New York UP, 1984. 
Labe, Louise. Oeuvres completes. Bd. François Rigolot. Paris: Flammarion, 1986.

La Clavière, R. de Maulde. Les Femmes de la Renaissance. Paris: Perrin, 1890.

Lemaire, Ria. "Bxplaining Away the Female subject: The Case of Medieval Lyric." Poetics Today vol. 7:4 (1986): 729-743.

Lazard, Madeleine. Images litteraires de la femme a la Renaissance. Paris: Presses Universitaires de Prance, 1985.

Maclean, Ian. The Renaissance Notion of Women. Cambridge: Cambridge University Press, 1980.

Marks, Blaine and Isabelle de Courtivron, eds. New French Feminisms. New York: Schocken Books, 1981.

Mathieu-Castellani, Gisele. "La Notion de genre." La Notion de genre la Renaissance. Bd. G. Demerson. Gendve: Bditions Slatkine, 1984. 17-34.

- "Les Modes du discours lyrique au XVIe sidcle." La Notion de genre la Renaissance. Ed. G. Demerson. Geneve: Editions Slatkine, 1984, 129-148.

- "La Parole chétive: Les Rymes de Pernette du Guillet." Litterature 73 February (1989): 47-60.

- "Les Marques du fóminin dans la parole amoureuse de Louise Labé." Publications de L"Universite do SaintEtienne (1990): 189-205.

- "Parole d'echo? Pernette au miroir des Rymes." L'Bsprit Créateur 30 (1990) 61-71.

Mills, Sara, et al. Feminist Readings/ Feminist's Reading. Charlottesville: University Press of Virginia, 1989.

Moi, Toril. "Peminist, Female, Feminine." The Feminist Reader: Essays in Gender and the Politics of Literay Criticism. Eds. Catherine Belsey and Jane Moore. New York: Basil Blackwe11, 1989. 117-132.

Nais, H. "La Notion de genre en poésie au XVİ̀e siecle: Btude lexicologique et semantique." La Notion de genre à la Renaissance. Bd. G. Demerson. Genève: Rditions Slatkine, 1984. 103-127.

Nash, Jerry C., ed. Pre-Pleiade Poetry. Lexington, KY: French Forum, 1985. 
- The Love Aesthetics of Maurice Sceve: Poetry and struggle. Cambridge: Cambridge University Press, 1991.

Pernette du Guillet. Rymes. Geneve: Libraire Droz, 1968.

Pratt, Annis. "The New Feminist Criticism." Feminist Criticism: Essays on Theory, Peotry and Prose. Bds. Cheryl L. Brown and Karen Olsen. Metuchen, N.J. and London: The Scarecrow Press Inc., 1978. 11-20.

Prine, Jeanne. "Louise Labe: Poet of Lyon." Women Writers of the Renaissance and the Reformation. Bd. Katherina $M$. Wilson. Athens and London: The University of Georgia Press, 1987. 132-157.

Rhode, Deborah L. Theoretical Perspectives on Sexual Difference. New Haven and London: Yale University Press, 1990 .

Richards, Barl Jeffrey, ed. and trans. The Book of the City of Ladies. New York: Persea Books, 1982.

Rigolot, Prançois. "Louise Labé et la redécouverte de Sappho." Nouvelle Revue du Seizieme siecle no. 1 (1983): 19-31.

"Gender v8. Sex Difference in Louise Labe's Grammar of Love. Rewriting the Renaissance: The Discourses of Sexual Difference in Barly Modern Europe. Chicago and London: The University of Chicago Press, 1986. 287-298.

- "Louige Labé et les dames lionnoises: Les Ambiguités de la censure." Le Signe et le texte: Etudes sur l'ecriture au XVIdme siecle en France. Bd. L.D. Kritzman. Lexington, KY: French Porum, 1990. 13-26.

Rose, Mary Beth, ed. Women in the Middle Ages and the Renaissance. Syracuse: Syracuse University Press, 1986.

Saulnier, Verdun L. "Etude sur Pernette du Guillet." Bibliothdque d'Humanisme et Renaissance: Travaux et documents. tome IV, Paris: Droz, 1944.

Sceve, Maurice. Délie: Objet de plus haute vertu. Paris: Bditions Gallimard, 1984.

Shahar, Shulamith. The Fourth Estate: A History of Women in the Middle Ages. Trans. Chaya Galai. London and New York: Rout ledge, 1983.

Showalter, Blaine. A Literature of Their Own. Princeton: Princeton UP, 1977. 
- Sexual Anarchy. New York: Penquin Books, 1990.

Spender, Dale. "Women and Literary History." The Feminist Reader: Essays in Gender and the Politics of Feminist Criticsm. Eds. Catherine Belsey and Jane Moore. New York: Basil Blackwell, 1989. 21-33.

Spaull, Sue. "Gynocriticism." Feminist Readings/ Feminist's Reading. Bd. Sara Mills, et al. Charlottesville: University Press of Virginia, 1989. 83-121.

and Kate Millard. "The Anxiety of Authorship." Feminist Readings/ Feminist's Reading. Bd. Sara Mills, et al. Charlottesville: UP of Virginia, 1989. 122-153.

Sullerot, Evelyne. "The Feminine (Matter of) Pact." New French Feminisms. Eds. Blaine Marks and Isabelle de Courtivron. New York: Schocken Books, 1981. 154-158.

Todd, Janet, ed. Gender and Literary Voice. vol. 1. New York and London: Holmes and Meier Publishers, Inc., 1980.

Wieser, Merry. "Women's Defense of Their Public Role." Women in the Middle Ages and the Renaissance. Bd. Mary Beth Rose. Syracuse: Syracuse University Press, 1986. 1-27.

Willard, Charity Cannon. "The Pranco-Italian Professional Writer: Christine de Pizan." Medieval Women Writers. Bd. Katherina M. Wilson. Athens: The University Press of Georgia, 1984. 333-363.

Wilson, Katherina M., ed. Medieval Women Writers. Athens: The University Press of Georgia, 1984.

ed. Women Writers of the Renaissance and the Reformation. Athens and London: The University Press of Georgia, 1987. 